\title{
Synthesis and Evaluation of Novel 1,2,6-Thiadiazinone Kinase Inhibitors as Potent Inhibitors of Solid Tumors
}

\author{
Andreas S. Kalogirou 1,2,*(D), Michael P. East ${ }^{3}$, Tuomo Laitinen ${ }^{4} \mathbb{D}$, Chad D. Torrice ${ }^{5}$, Kaitlyn A. Maffuid ${ }^{5}$, \\ David H. Drewry 6,7 (D), Panayiotis A. Koutentis ${ }^{2} \mathbb{D}$, Gary L. Johnson ${ }^{3,7}$, Daniel J. Crona ${ }^{5,7}$ (D) \\ and Christopher R. M. Asquith ${ }^{3, * \mathbb{D}}$
}

\section{check for} updates

Citation: Kalogirou, A.S.; East, M.P.; Laitinen, T.; Torrice, C.D.; Maffuid, K.A.; Drewry, D.H.; Koutentis, P.A.; Johnson, G.L.; Crona, D.J.; Asquith, C.R.M. Synthesis and Evaluation of Novel 1,2,6-Thiadiazinone Kinase Inhibitors as Potent Inhibitors of Solid Tumors. Molecules 2021, 26, 5911. https://doi.org/10.3390/ molecules26195911

Academic Editor: Baoan Song

Received: 6 September 2021

Accepted: 24 September 2021

Published: 29 September 2021

Publisher's Note: MDPI stays neutral with regard to jurisdictional claims in published maps and institutional affiliations.

Copyright: (c) 2021 by the authors. Licensee MDPI, Basel, Switzerland. This article is an open access article distributed under the terms and conditions of the Creative Commons Attribution (CC BY) license (https:// creativecommons.org/licenses/by/ $4.0 /)$.
1 Department of Life Sciences, School of Sciences, European University Cyprus, 6 Diogenis Str. Engomi, P.O. Box 22006, Nicosia 1516, Cyprus

2 Department of Chemistry, University of Cyprus, P.O. Box 20537, Nicosia 1678, Cyprus; koutenti@ucy.ac.cy

3 Department of Pharmacology, School of Medicine, University of North Carolina, Chapel Hill, NC 27599, USA; Michael_East@med.unc.edu (M.P.E.); gary_johnson@med.unc.edu (G.L.J.)

4 School of Pharmacy, Faculty of Health Sciences, University of Eastern Finland, 70211 Kuopio, Finland; tuomo.laitinen@uef.fi

5 Division of Pharmacotherapy and Experimental Therapeutics, Eshelman School of Pharmacy, University of North Carolina, Chapel Hill, NC 27599, USA; chad_torrice@med.unc.edu (C.D.T.);

kmaffuid@email.unc.edu (K.A.M.); crona@email.unc.edu (D.J.C.)

6 Structural Genomics Consortium, Eshelman School of Pharmacy, University of North Carolina, Chapel Hill, NC 27599, USA; david.drewry@unc.edu

7 Lineberger Comprehensive Cancer Center, School of Medicine, University of North Carolina, Chapel Hill, NC 27599, USA

* Correspondence: A.Kalogirou@euc.ac.cy (A.S.K.); chris.asquith@unc.edu (C.R.M.A.); Tel.: +357-22-559655 (A.S.K.); +1-919-491-3177 (C.R.M.A.)

Abstract: A focused series of substituted $4 H$-1,2,6-thiadiazin-4-ones was designed and synthesized to probe the anti-cancer properties of this scaffold. Insights from previous kinase inhibitor programs were used to carefully select several different substitution patterns. Compounds were tested on bladder, prostate, pancreatic, breast, chordoma, and lung cancer cell lines with an additional skin fibroblast cell line as a toxicity control. This resulted in the identification of several low single digit micro molar compounds with promising therapeutic windows, particularly for bladder and prostate cancer. A number of key structural features of the $4 \mathrm{H}-1,2,6$-thiadiazin-4-one scaffold are discussed that show promising scope for future improvement.

Keywords: thiadiazinone; bladder cancer; prostate cancer; pancreatic cancer; breast cancer; chordoma; lung cancer

\section{Introduction}

Heteroatom-rich scaffolds are underexplored in medicinal chemistry, potentially leading to missed opportunities [1-6]. One such ring system is the non S-oxidized 4H-1,2,6thiadiazinone, selected examples of which have applications as plant protectants [7-11], organic photovoltaics (OPVs) [12,13], liquid crystals [14], and potential anti-cancer agents [15]. The precursor to this 1,2,6-thiadiazinone scaffold, is the 3,4,4,5-tetrachloro-4H-1,2,6-thiadiazine (1) which was first reported in 1973 [16]. Subsequently, the chemistry was later developed to allow broad diversification [17]. Synthetic interest in thiadiazones/thiadiazines is currently focused around two scaffolds: 3,5-dichloro-4H-1,2,6-thiadiazin-4-one (2) and its precursor, 3,4,4,5-tetrachloro-4H-1,2,6-thiadiazine (1), which can be derived from dichloromalononitrile (Scheme 1) [18]. The substitution chemistry of both chlorines of 3,5-dichloro-4H-1,2,6thiadiazin-4-one (2) has been explored in detail and affords a versatile platform to prepare suitable 3,5-substituted derivatives.

3-Anilino-1,2,6-thiadiazinones occupy a similar chemical space to more commonly used medicinal chemistry scaffolds, including the mono- and di-anilinopyrimidines. The 
anilinopyrimidines are a common chemotype found in $\sim 10 \%$ of the clinically approved kinase inhibitor drugs, including palbociclib and ceritinib (Figure 1) [19]. Furthermore, anilinopyrimidines are found in a number of tool compounds for kinase interrogation, including GNF-2 for ABL [20], GSK854 for TNNi3K [21,22], and THZ-P1-2 for the PI5P4K isoforms [23]. The broad activity profile of the dianilinopyrimidine chemotype can also be seen within several kinase inhibitor screening sets, including PKIS, PKIS2, and KCGS, with more than 35 examples showing activity on $>400$ different protein kinases (excluding mutants) in either enzyme inhibition or affinity capture assays [24-26].

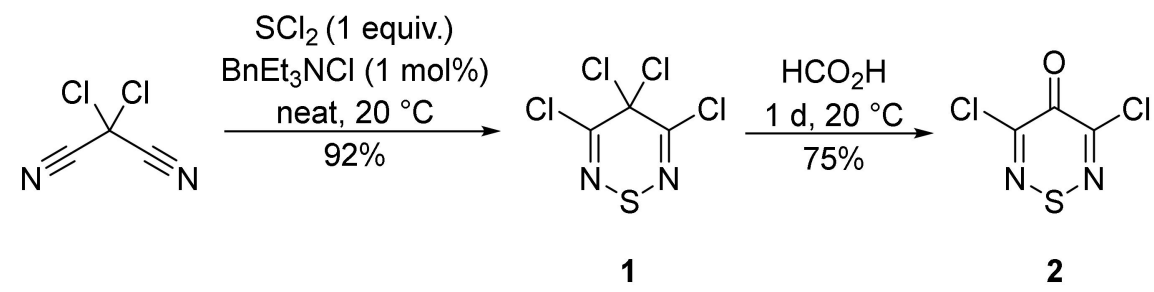

Scheme 1. Route to access 3,5-dichloro-4H-1,2,6-thiadiazin-4-one (2).<smiles>CC(=O)c1c(C)c2cnc(Nc3ccc(N4CCNCC4)cn3)nc2n(C2CCCC2)c1=O</smiles>

Palbociclib CDK4/CDK6<smiles>CCS(=O)(=O)c1ccc(S(=O)(=O)NC)c(Nc2cc(Nc3ccc(Cl)cn3)ncn2)c1</smiles>

GSK854 TNNi3K<smiles>Cc1cc(Nc2ncc(Cl)c(Nc3ccccc3S(=O)(=O)C(C)C)n2)c(OC(C)C)cc1C1CCNCC1</smiles>

Ceritinib ALK and others<smiles>NC(=O)c1cccc(-c2cc(Nc3ccc(OC(F)(F)F)cc3)ncn2)c1</smiles>

GNF-2

Abl kinases<smiles>CN(C)/C=C/C(=O)Nc1ccc(C(=O)Nc2cccc(Nc3cc(-c4c[nH]c5ccccc45)ncn3)c2)cc1</smiles>

THZ-P1-2

I5P4K all isoforms<smiles>[R][R]c1ccc(Nc2nsnc(Nc3ccccc3)c2=O)cc1</smiles>

3

General TZD Core

Figure 1. Representative examples of known anilinopyrimidines (highlighted in red) and general 1,2,6-thiadiazinone core (3).

The chemistry of 3,5-dichloro-4H-1,2,6-thiadiazin-4-one (2) is dominated by the substitution of the two chlorides. In particular, substitution can occur with $\mathrm{N}, \mathrm{O}$, and $\mathrm{S}$ nucleophiles as well as with organometallic reagents (carbon nucleophiles). Interestingly, while the synthesis of symmetrical 3,5-diarylthiadiazines is easy via Suzuki and Stille reactions [27], the synthesis of unsymmetrical analogues is more difficult as selective reaction of one of the two sites is not possible [28]. However, with amine or alkoxide nucleophiles, a stepwise reaction is possible as the first displacement is considerably more facile that the second one $[17,18]$. This allows for the preparation of unsymmetrical 3,5-diaminothiadiazines or even 3-amino-5-aryl derivatives via a combination of nucleophilic attack by an amine followed by a Suzuki reaction in the remaining C-5 position [15]. Moreover, a palladiumcatalyzed C-N coupling protocol was developed for the more difficult amino-displacement of the second chloride of thiadiazinone 4 to afford disubstituted derivatives 5 that avoids the use of elevated temperatures and excess amine (Scheme 2) [29]. 
<smiles>[R]c1nsnc(Cl)c1=O</smiles>

4

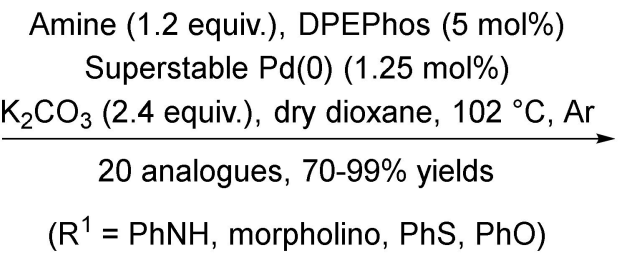

5

Scheme 2. C-N coupling of 5-subsituted 3-chlorothiadiazinones 4 with (het)arylamines.

\section{Results}

\subsection{Synthesis}

An in-depth analysis of the kinome-wide profiling of the dianilinopyrimidines in PKIS, PKIS2, and KCGS, and within the literature, led us to select a series of $\mathrm{R}^{1}$ and $\mathrm{R}^{2}$ substituent patterns (Figure 2, Table 1) that showed the broadest range of activity on human kinases. These compounds were designed to capture as much of the kinome as possible and, while unoptimized, they should provide attractive starting points for future work. In addition, several powerful hinge binding motifs were selected to enhance the scaffolds potential to capture extra kinases [30-32].

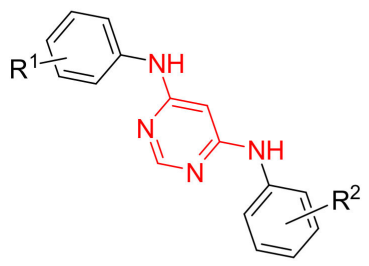

dianilinopyrimidine

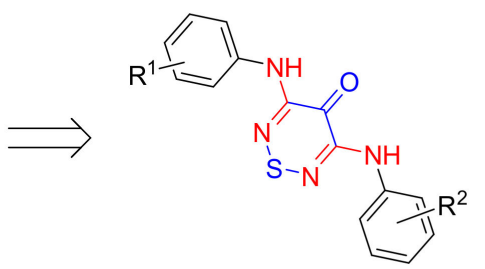

dianilinothiadiazinone

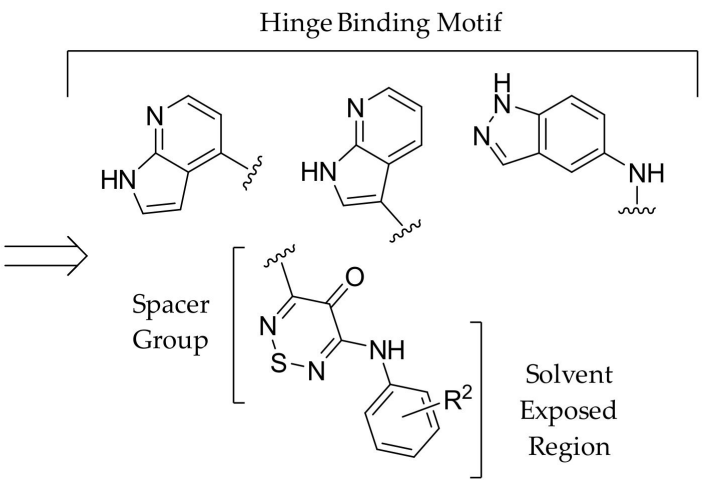

Figure 2. Design rational of novel 1,2,6-thiadiazinone analogues.

The corresponding 1,2,6-thiadiazin-4-ones (14-19, 21-25) were synthesized in twosteps starting from 3,5-dichloro-4H-1,2,6-thiadiazin-4-one (2) [18]. The first chloride of thiadiazinone 2 can be readily displaced by anilines and alkylamines by reaction with stoichiometric amounts of the amine (1 equiv.) and the base 2,6-lutidine (1 equiv.) in $\mathrm{EtOH}$, at ca. $0-20{ }^{\circ} \mathrm{C}$. The required 5-amino-3-chloro-4H-1,2,6-thiadiazin-4-ones 6-13 were isolated in 67-99\% yields with a chromatography-free work-up (Scheme 3).

Subsequently, scaffolds 6-12 were subjected to a Suzuki coupling with (1H-pyrrolo [2,3b]pyridin-4-yl)boronic acid. The seven desired products 14-19 were obtained in moderate to good yields (36-83\%) (Scheme 4).

A similar Suzuki coupling reaction was used to prepare 3-(4-methylpiperazin-1-yl)5-(1H-pyrrolo[2,3-b]pyridin-4-yl)-4H-1,2,6-thiadiazin-4-one (20) starting from 3-chloro-5(4-methylpiperazin-1-yl)-4H-1,2,6-thiadiazin-4-one (12) and (1H-pyrrolo[2,3-b]pyridin-4yl)boronic acid (Scheme 5). Moreover, the two 3,5-diamino-substituted thiadiazines 21 and 22 were prepared via our previously developed C-N coupling methodology [15] from 5-(4-methylpiperazin-1-yl)thiadiazin-4-one 12. The products were isolated in 64 and $92 \%$ yields, respectively (Scheme 5). 


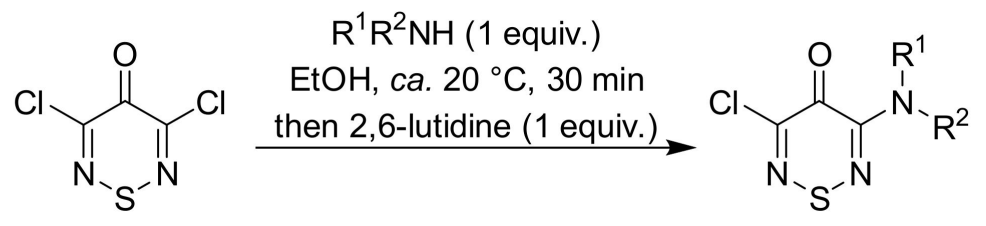

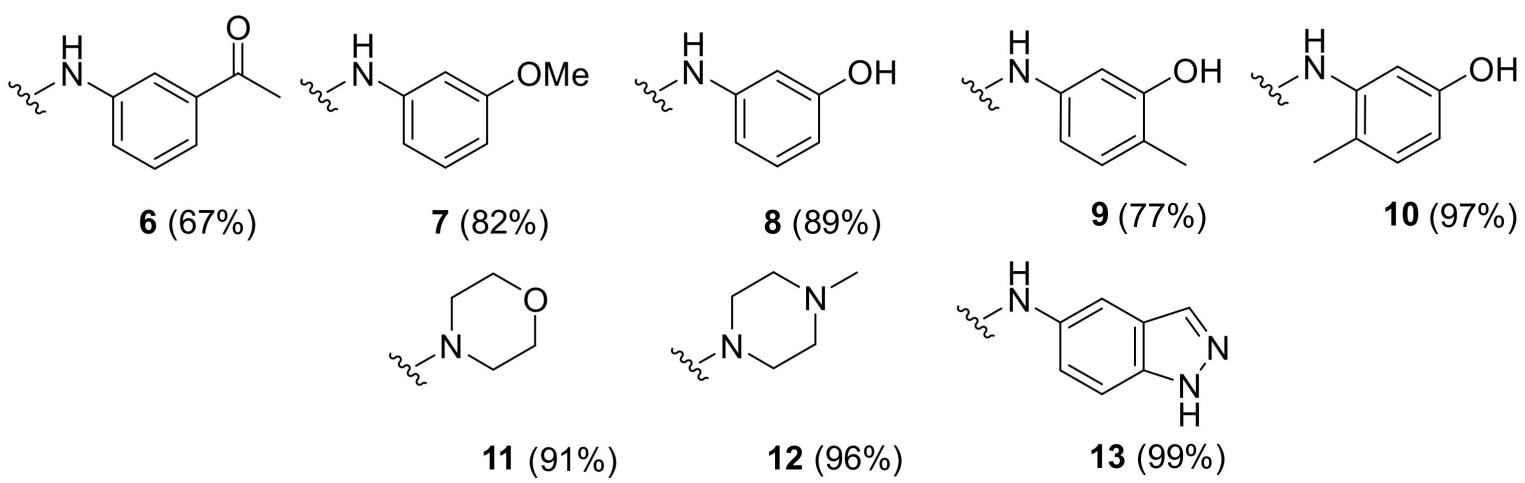

Scheme 3. Synthetic route to access 5-amino-3-chloro-4H-1,2,6-thiadiazin-4-ones 6-13.<smiles>[R]c1nsnc(Cl)c1=O</smiles>

6-12<smiles>Oc1ccnc2[nH]ccc12</smiles>

1.1 equiv.

\section{Superstable $\mathrm{Pd}(0)(5 \mathrm{~mol} \%)$ DPEPhos (5 mol\%), $\mathrm{K}_{2} \mathrm{CO}_{3}$ (2.4 equiv.) dioxane $/ \mathrm{H}_{2} \mathrm{O} 87: 13$, ca. $100^{\circ} \mathrm{C}, \mathrm{Ar}$}<smiles>[R]c1nsnc(-c2ccnc3[nH]ccc23)c1=O</smiles>

14-19<smiles>CCNc1cccc(C(C)=O)c1</smiles>

14<smiles>CCNc1cccc(OC)c1</smiles>

15<smiles>CCNc1cccc(O)c1</smiles>

16

$(20 \mathrm{~h}, 83 \%)$

(24 h, 36\%)<smiles>CCCCCCNc1ccc(C)c(NCCO)c1</smiles>

17<smiles>CCN1CCOCC1</smiles>

18

(3 h, 56\%)
19

$(22 \mathrm{~h}, 58 \%)$

Scheme 4. Suzuki couplings of thiadiazines 6-12 with (1H-pyrrolo[2,3- $b$ ]pyridin-4-yl)boronic acid to afford disubstituted products 14-19.<smiles>[R]c1nsnc(N2CCN(C)CC2)c1=O</smiles>

20<smiles>CN1CCN(c2nsnc(Cl)c2=O)CC1</smiles>

12

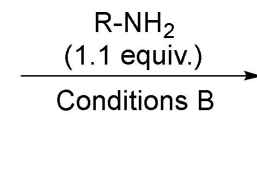

(1.1 ${ }^{2}{ }_{2}$

Conditions B<smiles>[R]Nc1nsnc(N2CCN(C)CC2)c1=O</smiles>

21 and 22<smiles>Cc1ccnc2[nH]ccc12</smiles>

$20(93 \%), 21(64 \%)$<smiles>Cc1ccc2[nH]ncc2c1</smiles>

$22(92 \%)$

Scheme 5. Scaffold diversification with tertiary amine substituent to afford 20-22.

Finally, a modified Suzuki coupling procedure was required for the synthesis of the 3-[(1H-indazol-5-yl)amino]-4H-1,2,6-thiadiazin-4-ones. A brief optimization showed that the combination of the catalyst $\mathrm{Pd}(\mathrm{dppf}) \mathrm{Cl}_{2}(10 \mathrm{~mol} \%)$ and the base $\mathrm{Na}_{2} \mathrm{CO}_{3}$ (2 equiv.), in 
dioxane $/ \mathrm{H}_{2} \mathrm{O} 90: 10$, in a sealed tube at ca. $140{ }^{\circ} \mathrm{C}$ was required to drive the reactions to completion. The four desired products $\mathbf{2 3 - 2 6}$ were obtained in medium to good yields of $68-92 \%$ (Scheme 6).<smiles>O=c1c(Cl)nsnc1Nc1ccc2[nH]ncc2c1</smiles>

13<smiles>Oc1cccc(I)c1</smiles>

23

$(1.5 \mathrm{~h}, 68 \%)$
$\mathrm{ArB}(\mathrm{OH})_{2}$ (2 equiv.), $\mathrm{Pd}(\mathrm{dppf}) \mathrm{Cl}_{2}(10 \mathrm{~mol} \%)$ $\mathrm{Na}_{2} \mathrm{CO}_{3}$ (2 equiv.), dioxane/ $\mathrm{H}_{2} \mathrm{O} 90: 10$ sealed tube, ca. $140{ }^{\circ} \mathrm{C}, \mathrm{Ar}$

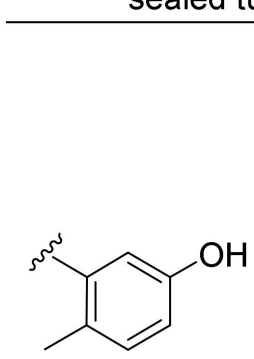

24
$(1.5 \mathrm{~h}, 69 \%)$<smiles>COc1cccc(CC(C)(C)C)c1</smiles>

25<smiles>O=c1c(Br)nsnc1Nc1ccc2[nH]ncc2c1</smiles>

23-26

Scheme 6. Suzuki couplings of 5-chloro-3-[(1H-indazol-5-yl)amino]-4H-1,2,6-thiadiazin-4-one (13).

It is important to note that the stability of dianilinothiadiazinones in biological systems has previously been assessed [15]. 3,5-Bis(phenylamino)-4H-1,2,6-thiadiazin-4-one [18] is stable to neutral, acidic, or slightly basic aqueous conditions, the presence of amine or thiol nucleophiles, and oxidizing and reducing conditions. We similarly tested thiadiazinone $\mathbf{1 6}$ from our current study and found the same results.

\subsection{Cancer Cell Screening}

Compounds 14-26 were screened on an array of cancer cell lines to explore the structural requirements for anti-cancer activity within the 1,2,6-thiadiazinone scaffold (Table 1). This included pancreatic, bladder, prostate, breast, chordoma, and lung cancer cell lines while a skin fibroblast cell line was used as a toxicity control [33-36]. These cancer cell lines present different drug resistance profiles and when combined in a panel, each represents a distinct therapeutic challenge to overcome [37].

The first analogue 3-[(3-acetylphenyl)amino]-5-(1H-pyrrolo[2,3-b]pyridin-4-yl)-4H1,2,6-thiadiazin-4-one (14) demonstrated limited inhibition across the panel of cell lines with the most inhibition shown on the bladder cancer cell line $\left(\mathrm{IC}_{50}=15 \mu \mathrm{M}\right)$. Switching from the acetyl substitution $\mathbf{1 4}$ to the methoxy 15 showed no improvement across the panel. Removal of the methyl on the methoxy 15, to afford a hydroxy functionality 16, led to a 10 -fold increase in potency on the bladder cancer cell line $\left(\mathrm{IC}_{50}=1.6 \mu \mathrm{M}\right)$ with no toxicity in the WS- 1 cell line $\left(\mathrm{IC}_{50}=>100 \mu \mathrm{M}\right)$. The introduction of a 4-methyl substituent 17 removed weak inhibition on PANC1 and UCH-1 but did not show any improvement on the other cell lines in the panel. Interestingly, the introduction of a 2-methyl substituent 18 removed nearly all anti-cancer activity. Switching to the aliphatic a morpholine substituent again changed the preference toward pancreatic $\left(\mathrm{IC}_{50}=11 \mu \mathrm{M}\right)$ and prostate $\left(\mathrm{IC}_{50}=14 \mu \mathrm{M}\right)$ cancers with little activity towards bladder and the other cell lines.

We then sought to look at changing the hinge binding motif using the methyl piperazine as the fixed substituent. This tertiary amine substitution affords compounds with favorable properties [38-42]. However, in the case of our three powerful hinge binders [30], we observed very limited activity across both azaindoles, 4-postion 20 and 6-position 21, along with the indazole 22 . The indazole 22 showed a small amount of toxicity in the WS-1 cell line $\left(\mathrm{IC}_{50}=24 \mu \mathrm{M}\right)$.

Switching to the indazole scaffold afforded a different potential hinge binding orientation. 5-(3-Hydroxyphenyl)-3-[(1H-indazol-5-yl)amino]-4H-1,2,6-thiadiazin-4-one (23) had only weak activity in the panel of cell lines but also showed no toxicity on the WS-1 cell line $\left(\mathrm{IC}_{50}=>100 \mu \mathrm{M}\right)$. The introduction of a 2-methyl group to compound 23 to afford 24 
improved the overall anti-cancer profile of the scaffold, with the most potency observed on breast cancer cell line $\left(\mathrm{IC}_{50}=13 \mu \mathrm{M}\right)$ and no toxicity on WS-1. The introduction of the methoxy group at the 3-position of thiadiazinone $\mathbf{2 5}$ changed the anti-cancer profile significantly with increased potency against bladder cancer $\left(\mathrm{IC}_{50}=13 \mu \mathrm{M}\right)$. Finally, we tested an isosteric replacement for the 3-methoxy the 3-fluoro and introduced a 4-pyridyl substitution pattern to afford compound 26; this substituent orientation is observed in a number of kinase tool compounds [43,44]. 5-(2-Fluoropyridin-4-yl)-3-[(1H-indazol-5yl)amino]-4H-1,2,6-thiadiazin-4-one (26) demonstrated potent activity against both bladder $\left(\mathrm{IC}_{50}=8.4 \mu \mathrm{M}\right)$ and prostate $\left(\mathrm{IC}_{50}=5.7 \mu \mathrm{M}\right)$ cancer with no toxicity on the WS-1 cell line $\left(\mathrm{IC}_{50}=>100 \mu \mathrm{M}\right)$.

Table 1. Activity of anilinothiadiazinones on a panel of seven cancer cell lines.

\begin{tabular}{|c|c|c|c|c|c|c|c|c|c|c|}
\hline Compound & 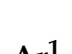 & 2 & 5637 & DU145 & PANC1 & MCF7 & UCH1 & $\mathrm{UCH} 2$ & A431 & WS-1 \\
\hline сотрота & $\mathbf{A r} \mathbf{r}^{\mathbf{1}}$ & $A \mathbf{r}^{2}$ & \multicolumn{8}{|c|}{$\mathrm{IC}_{50}(\mu \mathrm{M})^{\mathrm{a}}$} \\
\hline 14 & & & 15 & $>100$ & $>100$ & $>100$ & 58 & $>100$ & $>100$ & 92 \\
\hline 15 & & & 15 & $>100$ & $>100$ & $>100$ & 67 & $>100$ & $>100$ & $>100$ \\
\hline 16 & & & 1.6 & 41 & 33 & 18 & 46 & $>100$ & $>100$ & $>100$ \\
\hline 17 & & & 2.1 & 23 & $>100$ & 14 & $>100$ & $>100$ & $>100$ & $>100$ \\
\hline 18 & & & 55 & $>100$ & $>100$ & $>100$ & $>100$ & $>100$ & $>100$ & $>100$ \\
\hline 19 & & & $>100$ & 14 & 11 & 46 & $>100$ & $>100$ & $>100$ & $>100$ \\
\hline 20 & & & $>100$ & $>100$ & $>100$ & $>100$ & nt & nt & nt & nt \\
\hline 21 & & & $>100$ & 51 & $>100$ & $>100$ & 97 & $>100$ & $>100$ & $>100$ \\
\hline 22 & & & $>100$ & 50 & $>100$ & 25 & $>100$ & $>100$ & $>100$ & 24 \\
\hline 23 & & & $>100$ & 84 & $>100$ & 92 & 71 & $>100$ & $>100$ & $>100$ \\
\hline 24 & & & $>100$ & 15 & 26 & 13 & 67 & $>100$ & $>100$ & $>100$ \\
\hline 25 & & & 13 & $>100$ & $>100$ & 38 & 52 & 99 & $>100$ & 71 \\
\hline 26 & & & 8.4 & 5.7 & $>100$ & 50 & 84 & $>100$ & $>100$ & $>100$ \\
\hline
\end{tabular}




\subsection{Kinome Profiling of Thiadiazinones $\mathbf{1 6}, \mathbf{1 7}$, and $\mathbf{2 6}$}

We then assessed the kinome profile of thiadiazinones 16,17 , and 26 all at $1 \mu \mathrm{M}$ using a multiplexed kinase inhibitor bead set and quantitative mass spectrometry for detection of kinase peptides (MIB-MS) [36,45,46]. The MIB-MS proteomics was able to detect between 350 and 400 kinases in the cell lysates and competitive displacement of specific kinases from the beads was used to determine the kinome profile of the thiadiazinone kinase inhibitors. Compound 16 showed a narrow spectrum kinome profile with weak interactions on MAP4K5, MAP4K3, PRKCD, and PKN1 just below the threshold (Figure 3). Compound 17 also had a narrow spectrum kinome profile, with AKT2, MAP2K4, MAP2K1, and STK35 being just below the threshold (Figure 4). Compound $\mathbf{2 6}$ had a narrow spectrum kinome profile but was a weak inhibitor, showing affinity for ACVR1B, ACVR2A, and STK35 (Figure 5).
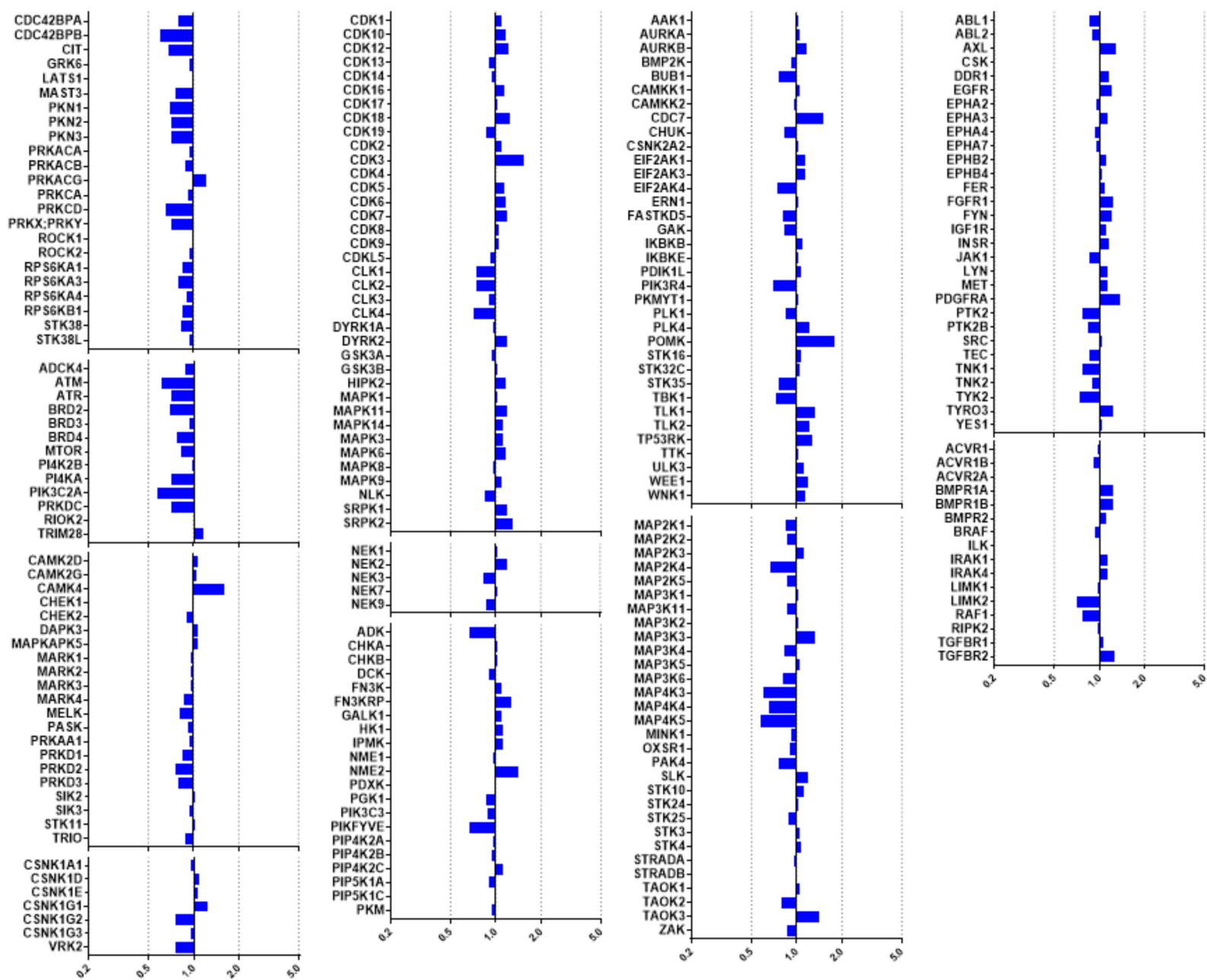

Figure 3. MIBS kinome profiling for thiadiazinone $16(1 \mu \mathrm{M}) / \mathrm{DMSO}$.

\subsection{Modelling of Hits from Kinome Profiling on Thiadiazinones 16, 17, and 26}

The key hits on thiadiazinones 16, 17, and 26 from the MIBS profiling, were then modelled to understand their interactions in the respective ATP binding site (Figures 6-8). First, compound 16 was analyzed against MAP4K5 [47], MAP4K3 [48], PRKCD [49], and PKN1 [50]. Docking of the compounds was performed using Schrödinger Maestro [51]. Before docking into the ATP-binding site, prepared from the PDB structure as needed, the compounds were minimized using LigPrep. The docking pose that placed the azo-indole in a position to make a hydrogen bond from the backbone $\mathrm{NH}$ of the hinge region of 
the respective kinases was the most favorable (Figure 6A-D). The 1,2,6-thiadiazinone is relatively passive, acting as a linker to the solvent region where the phenolic alcohol can form a series of different hydrogen bonding interactions. In the case of MAP4K5, MAP4K3, and PRKCD (Figure 6A-C), this is both accepting and donating, forming a rigid fixture at the mouth of the ATP binding site. PKN1 is not able to accommodate this accepting interaction, so there is only a much weaker hydrogen bonding interaction with D764 and no interaction with K748.
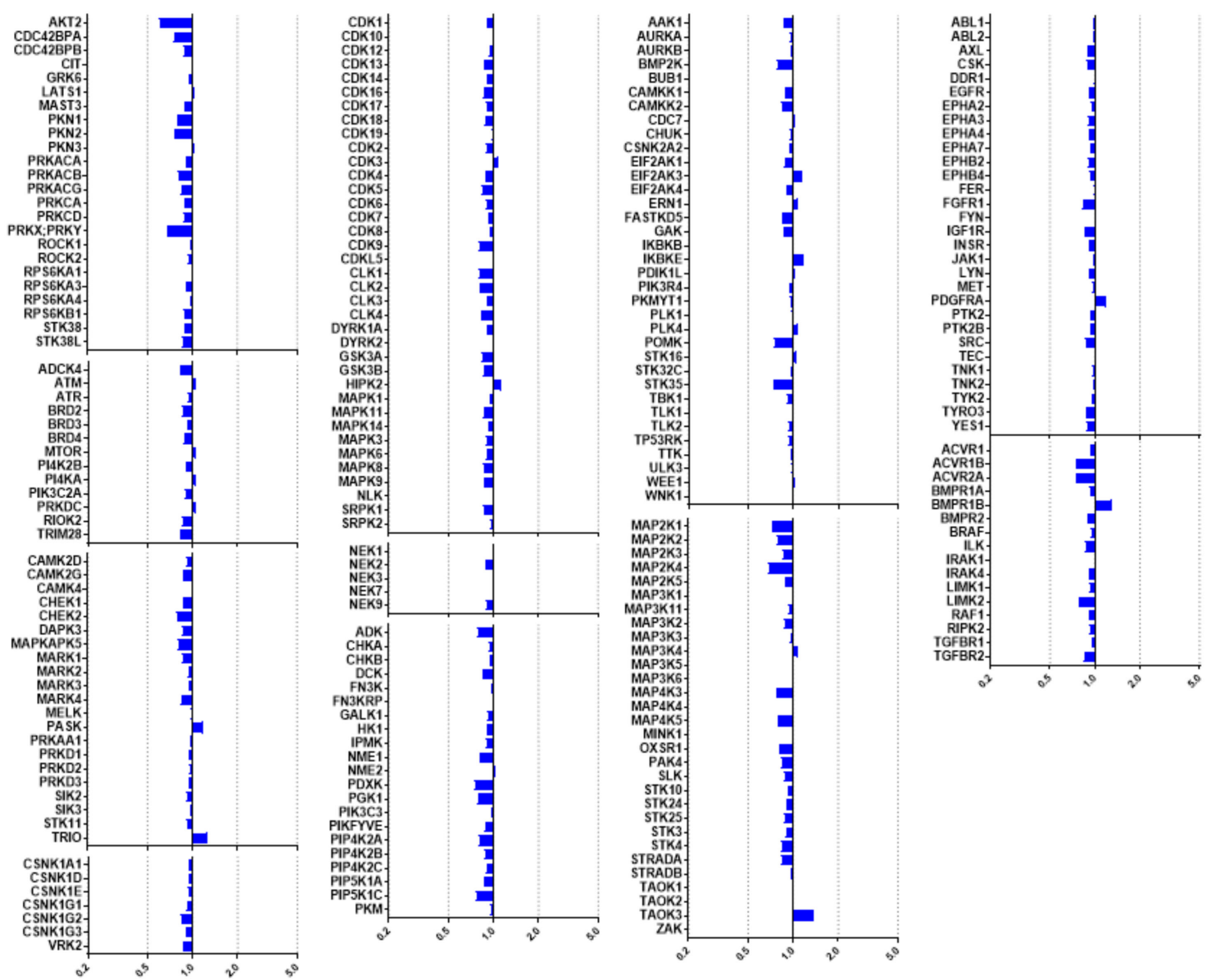

Figure 4. MIBS kinome profiling for thiadiazinone $17(1 \mu \mathrm{M}) / \mathrm{DMSO}$.

In the case of compound 17 (Figure 7), the azo-indole was similarly positioned at the hinge in both AKT2 [52] and STK35 [47,53]. However, the rest of the molecule was not orientated differently in both cases. This enabled additional interactions in both cases where the 1,2,6-thiadiazinone is actively involved, forming a hydrogen bond with the residue T292 in AKT2 and D323 in STK35. This is in addition to a hydrogen bond interaction by the phenolic alcohol with N280 and N365 in AKT2 and STK35, respectively.

Thiadiazinone 26 (Figure 8), similarly to compounds 16 and 17, formed a strong hydrogen bond in the hinge region of ACVR1B [54] and STK35 [53]. In AVCR1B, the 1,2,6-thiadiazinone was passive with no strong interactions. The pyridine nitrogen did, however, form a hydrogen bond with a solvent-exposed lysine residue K337. In the case of STK35, the 1,2,6-thiadiazinone was actively involved, forming an interaction with a solvent-exposed lysine residue K231. This was in addition to another hydrogen bond interaction with the bringing amine between the indazole and 1,2,6-thiadiazinone. The ATP was too shallow to accommodate the pyridine interaction as seen in AVCR1B and interactions involved with the phenolic alcohol of compound 17. 

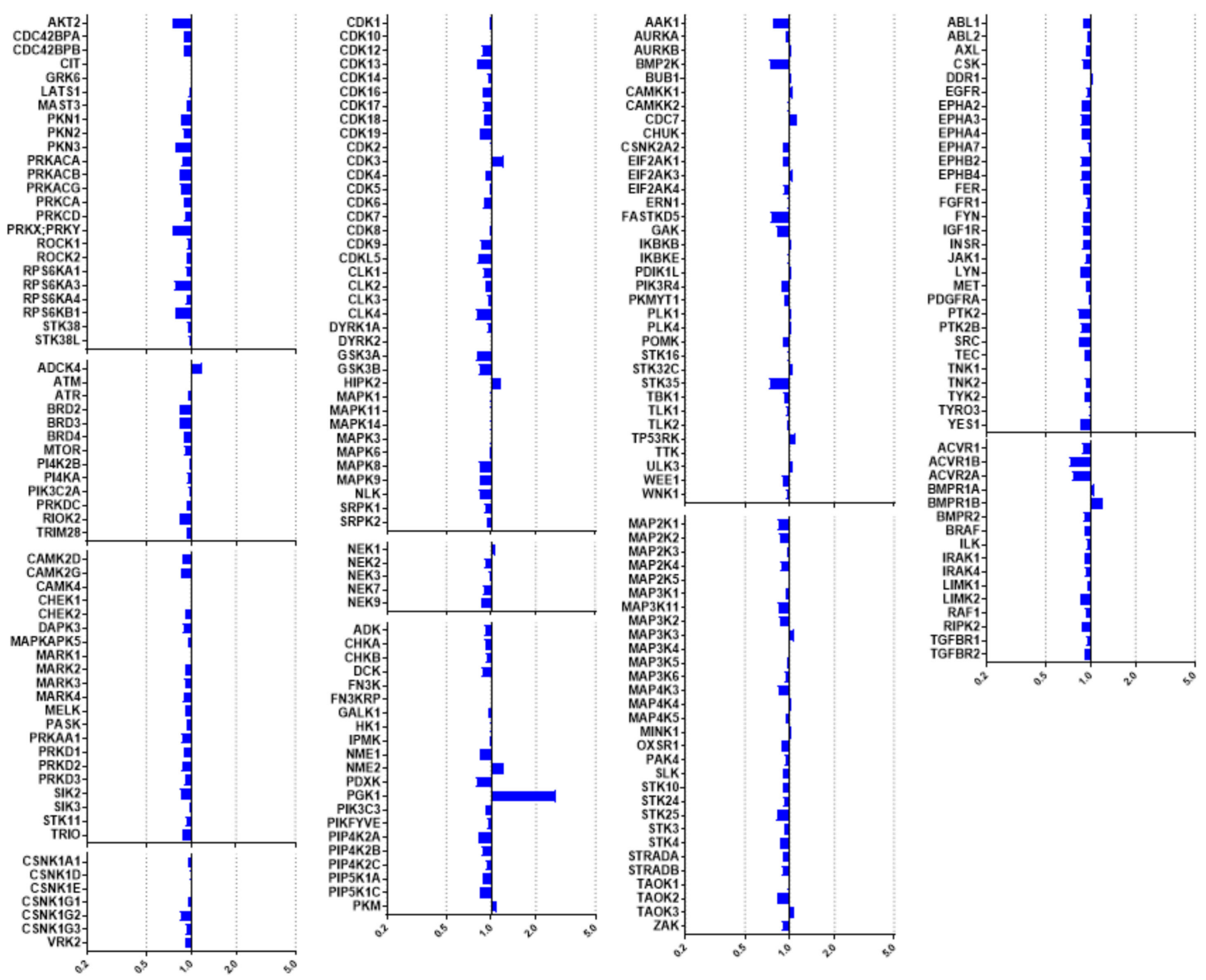

Figure 5. MIBS kinome profiling for thiadiazinone $26(1 \mu \mathrm{M}) / \mathrm{DMSO}$.

A
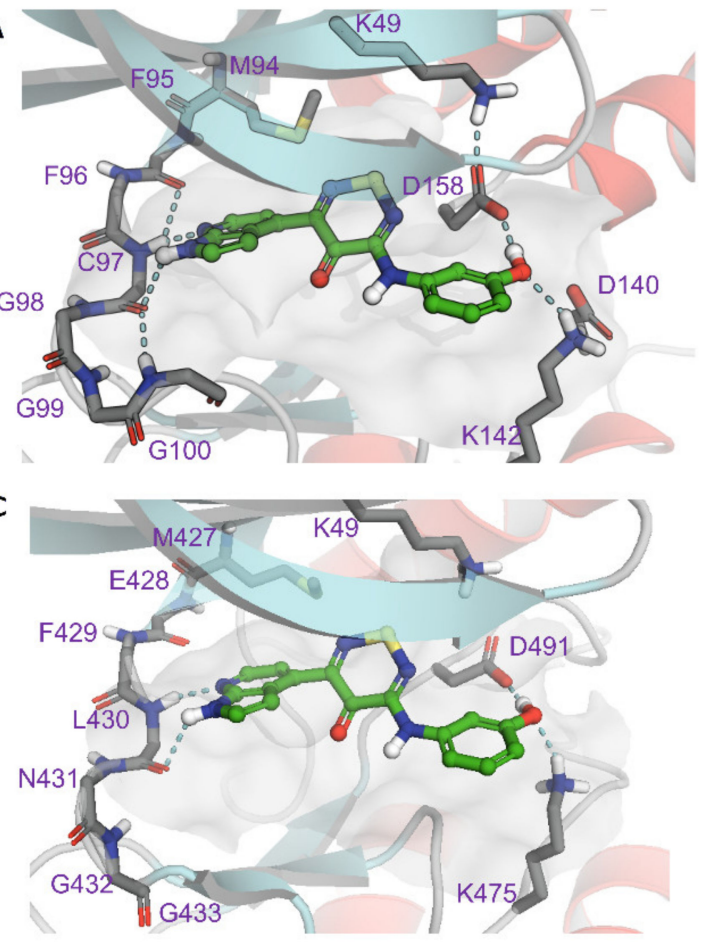

B

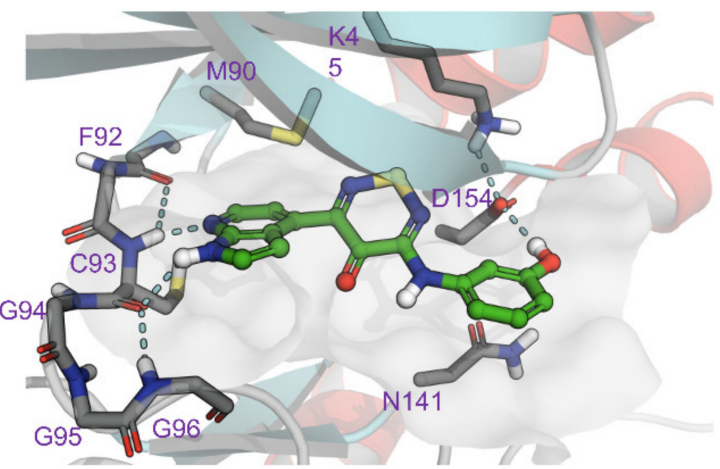

D

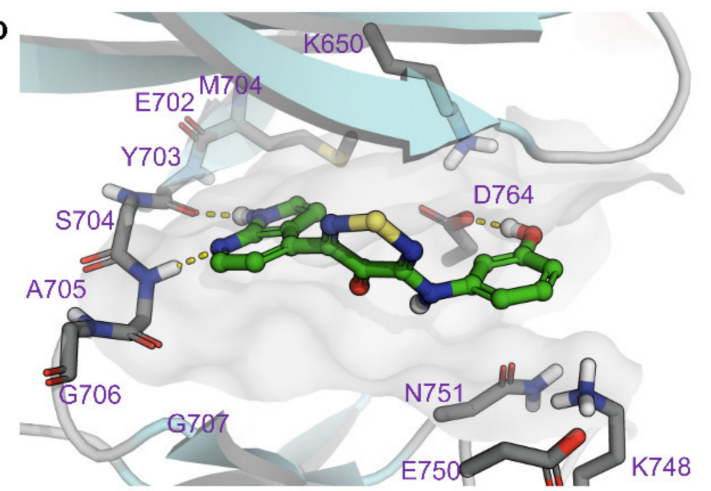

Figure 6. Molecular modeling of 16 on MIBS kinome profiling hits: (A) MAP4K5; (B) MAP4K3; (C) PRKCD; and (D) PKN1. 

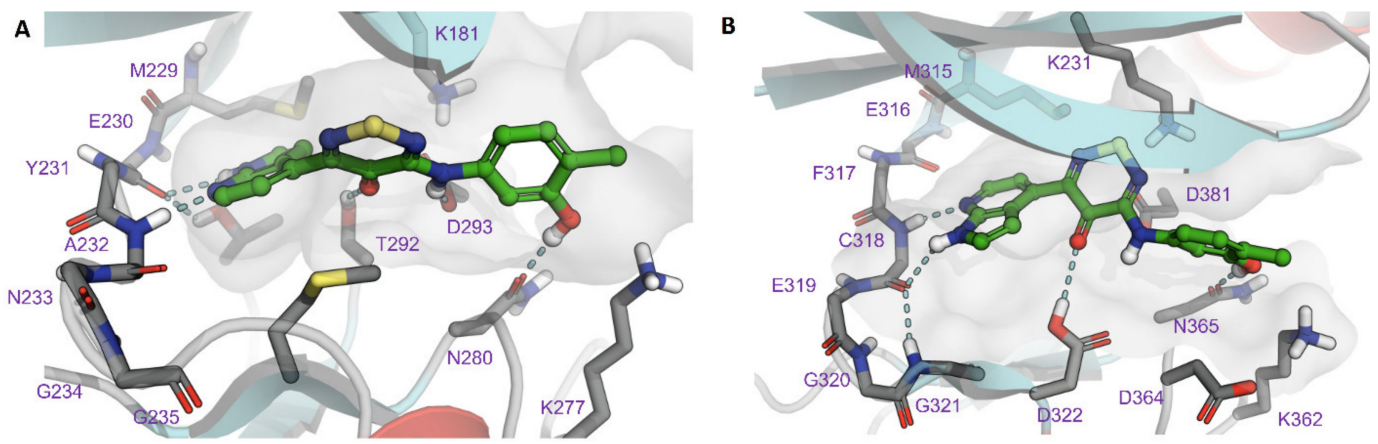

Figure 7. Molecular modeling of thiadiazinone $\mathbf{1 7}$ on MIBS kinome profiling hits: (A) AKT2 and (B) STK35.
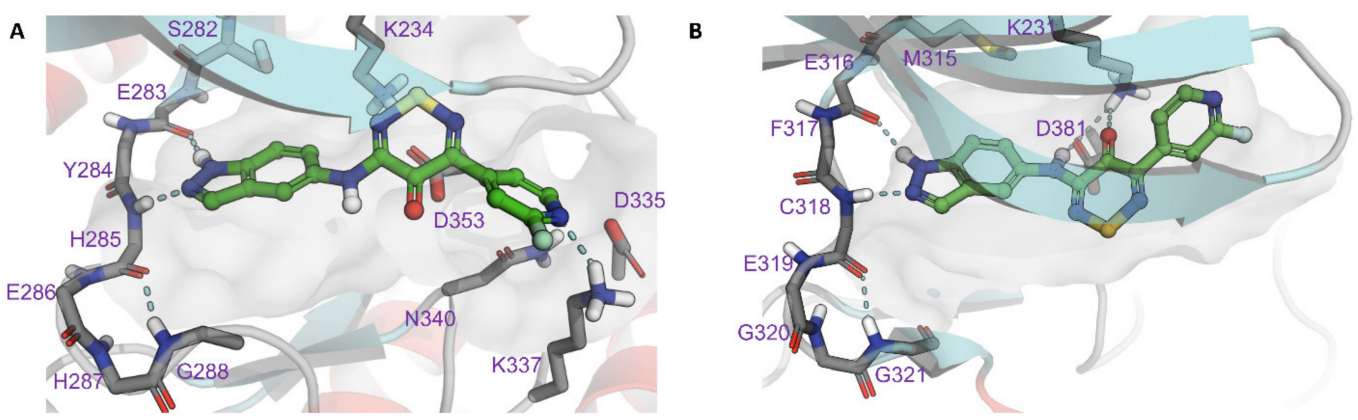

Figure 8. Molecular modeling of thiadiazinone 26 on MIBS kinome profiling hits: (A) ACVR1B and (B) STK35.

\section{Discussion}

Previously, we demonstrated that the 4H-1,2,6-thiadiazin-4-one chemotype can function as an ATP-competitive kinase inhibitor, acting as a novel hinge binding motif. This was also the first report of a protein co-crystallization with this rare heterocycle [15]. We have now expanded the repertoire of the $4 H-1,2,6$-thiadiazin-4-one as a spacer unit within a kinase inhibitor affording unique chemical properties. The electronics of the $4 H-1,2,6-$ thiadiazin-4-one core allows for negative charge transfer from the sulfur atom towards the conjugated system [55]. This electronic property, exploited in solar cell applications, can partly explain the general lack of kinome promiscuity compared to the dianilinopyrimidine [15]. The modular synthesis and relative narrow kinome spectrum make the $4 H-1,2,6$-thiadiazin-4-one an attractive chemotype for further development.

The chemical tractability of the protein kinases makes them an attractive target for drug development. Over 90 drugs have been approved that target the ATP binding site, predominantly in the field of oncology $[19,56]$. However, with emerging indications beyond cancer including the treatment of chronic diseases, such as inflammation and neurodegeneration, along with the emergence of resistance, development of compounds with improved potency and selectivity profiles are essential to remain at the cutting edge $[57,58]$. A number of indirect assays exist to assess the inhibitor affinity, and binding assays are some of the most accurate and robust methods to measure the potency and selectivity of ATP-competitive kinase inhibitors [59-63]. Ligand binding displacement assays are particularly important to provide an accepted form of direct measurement of kinase inhibition in drug optimization of ATP-binding site inhibitors for neglected kinases, where there are currently no robust and validated enzyme activity assays [59,63].

Our results afford new data on a series of interesting starting points for further optimization towards new kinases targets including MAP4K3, MAP4K5, PRKCD, PKN1, AKT2, STK35, and ACVR1B, all of which have some indication in proliferation. The early kinome data, combined with modelling and the accompanying phenotype on bladder cancer, afford exciting prospects for this scaffold. This work firmly puts 1,2,6-thiadiazin-4- 
one into the medicinal chemistry toolbox and provides another example of the application of sulfur heterocycles in drug design.

\section{Materials and Methods}

\subsection{Cancer Cell Line Screening Panel}

U-CH1 and U-CH2 cell lines were cultured in 80:20 IMDM/RPMI-1640 medium supplemented with $10 \%$ fetal bovine serum (FBS), $1 \%$ penicillin/streptomycin in gelcoated flasks. A-431, PANC-1, and WS1 cell lines were cultured in DMEM medium supplemented with 10\% FBS and 1\% penicillin/streptomycin. DU145 and MCF-7 cells were cultured in MEM medium supplemented with 10\% FBS and 1\% penicillin/streptomycin. 5637 cells were cultured in RPMI-1640 medium supplemented with 10\% FBS and 1\% penicillin/streptomycin. Cells were seeded in 384-well plates and were treated with test compound in quadruplicate $24 \mathrm{~h}$ after plating. Cell viability was assessed at $72 \mathrm{~h}$ using alamarBlue (ThermoFisher, Waltham, MA, USA). Fluorescence was measured using Tecan Infinite 200 PRO (Tecan, Männedorf, Switzerland) plate reader with an excitation at $535 \mathrm{nM}$ and emission at $590 \mathrm{nM}$. IC 50 values were determined by nonlinear regression using GraphPad PrismTM software (GraphPad Software Inc., San Diego, CA, US). (Positive controls: MCF7, lapatinib $\mathrm{IC}_{50}=6.3 \mu \mathrm{M}$ [64]; 5637, pazopanib $\mathrm{IC}_{50}=15 \mu \mathrm{M}$ [65]; PANC1, panobinostat $\mathrm{IC}_{50}=1.0 \mu \mathrm{M}$ [66]; DU145, docetaxel $\mathrm{IC}_{50}=5 \mathrm{nM}$ [67]; UCH1, gefitinib $\mathrm{IC}_{50}=1.4 \mu \mathrm{M}$ [36]; $\mathrm{UCH} 2$, gefitinib $\mathrm{IC}_{50}=23 \mu \mathrm{M}$ [36]; A431, lapatinib $\mathrm{IC}_{50}=100 \mathrm{nM}$ [68]; WS-1, lapatinib $\left.\mathrm{IC}_{50}=13 \mu \mathrm{M}[36]\right)$.

\subsection{MIBS Profiling Methods}

Previously described [45]. Briefly, multiplexed inhibitor beads (MIBS) affinity chromatography/MS analysis: SUM159 cells were cultured in a 50:50 mixture of DMEM and Nutrient Mixture F-12 medium (Gibco) supplemented with 5\% fetal bovine serum, 1\% anti/anti, $5 \mathrm{mg} \mathrm{mL}^{-1}$ insulin, and $1 \mathrm{mg} \cdot \mathrm{mL}^{-1}$ hydrocortisone. Cells were maintained at $37^{\circ} \mathrm{C}$ in a humidified $5 \% \mathrm{CO}_{2}$ atmosphere. SUM159 cells were grown to $80 \%$ confluency, washed twice with PBS, and harvested by scraping cells in lysis buffer $50 \mathrm{mM}$ HEPES, pH 7.5, $150 \mathrm{mM} \mathrm{NaCl}, 0.5 \%$ Triton X-100, 1 mM EDTA, 1 mM EGTA, $10 \mathrm{mM} \mathrm{NaF}, 2.5 \mathrm{mM}$ $\mathrm{Na}_{3} \mathrm{VO}_{4}$, complete protease inhibitor cocktail (Roche, Basel, Switzerland), phosphatase inhibitor cocktail 2, and 3 (Sigma, St. Louis, MO, USA)]. Lysates were sonicated then clarified by centrifugation at $14000 \mathrm{~V}$ g for $15 \mathrm{~min}$ at $4{ }^{\circ} \mathrm{C}$. Lysate was then filtered through a $0.2 \mathrm{~mm}$ syringe filter and frozen at $-80^{\circ} \mathrm{C}$ until use. Protein concentration was quantified using a Bradford assay the day of the experiment. DMSO or the indicated concentration of 16,17 , and 26 were added to lysate containing $4 \mathrm{mg}$ of total protein. Lysates were vortexed briefly then incubated for $30 \mathrm{~min}$ on ice. Kinases were affinity purified as previously described [46]. Briefly, lysates were diluted to $1.33 \mathrm{mg} \mathrm{mL}^{-1}$ with lysis buffer then $\mathrm{NaCl}$ concentration brought to $1 \mathrm{M}$.

Diluted lysates were passed over a mixture of $25 \mathrm{~mL}$ of settled beads of each of the following inhibitors conjugated to ECH Sepharose beads: Purvalanol B, PP58, VI16832, UNC21474A, UNC8088A, and $37.5 \mathrm{~mL}$ of settled beads conjugated to CTx-0294885 and VI-16832 [69]. The kinase inhibitor-bead conjugates were previously equilibrated in high-salt buffer (50 mM HEPES pH 7.5, $1 \mathrm{M} \mathrm{NaCl}, 0.5 \%$ Triton X-100, 1 mM EDTA, and $1 \mathrm{mM}$ EGTA). MIBs columns were sequentially washed with high-salt buffer, lowsalt buffer (50 mm HEPES pH 7.5, $150 \mathrm{mM} \mathrm{NaCl}, 0.5 \%$ Triton X-100, $1 \mathrm{mM}$ EDTA, and $1 \mathrm{mM}$ EGTA), and SDS buffer (50 mm HEPES pH 7.5, $150 \mathrm{~mm} \mathrm{NaCl}, 0.5 \%$ Triton X-100, $1 \mathrm{~mm}$ EDTA, $1 \mathrm{~mm}$ EGTA, and $0.1 \%$ SDS). Proteins were eluted by boiling samples in elution buffer (100 mM Tris. $\mathrm{HCl} \mathrm{pH} \mathrm{6.8,} \mathrm{0.5 \%} \mathrm{SDS,} \mathrm{and} 1 \% \beta$-mercaptoethanol) for $15 \mathrm{~min}$ twice. Dithiothreitol (DTT) was added to a final concentration of $5 \mathrm{~mm}$ and samples were incubated at $60^{\circ} \mathrm{C}$ for $25 \mathrm{~min}$. Samples were then cooled to room temperature on ice and alkylated by adding iodoacetamide to a final concentration of $20 \mathrm{~mm}$ for $30 \mathrm{~min}$ in the dark at room temperature. Samples were then concentrated in 10K Amicon Ultra centrifugal concentrators (Millipore, Burlington, MA, USA) followed by methanol and chloroform 
precipitation of proteins. The final protein pellets were re-suspended in $50 \mathrm{mM}$ HEPES $\mathrm{pH} 8.0$ and incubated with trypsin at $37^{\circ} \mathrm{C}$ overnight. Residual detergent was removed by three sequential ethyl acetate extractions then desalted using Pierce $\mathrm{C}_{18}$ spin columns (Thermo Scientific, Waltham, MA, USA) according to the manufacturer's protocol.

\subsection{Molecular Modelling Methods}

\subsubsection{Ligand Preparation}

Structures of small molecules were parametrized and minimized using the LigPrep module of Schrodinger 2020-4 suite employing OPLS3e force field [51].

\subsubsection{Protein Preparation}

The kinase a crystal structures co-crystallized with substrate analogues or inhibitors were downloaded from RCSB-databank: MAP4K3-(PDB:5J5T) [70]; PKN1-(PDB:4OTI) [71]; AKT2-(PDB:2X39) [72]. The structures were H-bond optimized and minimized using the standard protein preparation procedure of Schrödinger suite.

\subsubsection{Development of Homology-Based Model}

Three-dimensional models of ACVR1B, STK35, and MAP4K5 were developed using Biovia Discovery Studio 2019 program (Dassault Systèmes, San Diego, CA, USA). The human forms of target sequences were downloaded from uniport, and psi-blast searched against the PDB-template database. Pre-aligned template structures (ACVR1B(PDB:5E8X) [73], STK35-(PDB:3MA6), and MAP4K5-(PDB:5J5T) [70]) were downloaded to Discovery Studio and Alignments to corresponding kinase domains. The sequence of corresponding unknown kinase was then aligned to template structures. The models were built using standard settings of the modeler: optimization level = high, Number of models $=20$, Refine loops $=$ false, original ligands were copied from templates. Models were then ranked according to the PDF score and highest ranked models were uploaded to Maestro for protein preparation protocol. Models of AVCR1B and MAP4K5 were also successfully generated using protein structure prediction functionality available at GalaxyWEB-modelling site (http: / / galaxy.seoklab.org/ Accessed on: 6 September 2021), and cross checked with in-house generated models. During the final stage of this study, several AlphaFold structures available including ACVR1B, STK35, and MAPK5 were downloaded [74], prepared, and aligned to compare the positions of key residues with previously generated in-house models, which were consistent with our findings (data not shown).

\subsubsection{Molecular Docking}

The ligand docking was performed using an induced fit protocol using the standard settings of Schrodinger suite 2020-4 (up to 20 models were generated, dockings were done using SP-level of IFD-setting during Glide docking and redocking steps). The centers of glide grids were set to the centroid of co-crystallized ligands or template-derived ligands. The highest ranked docking poses were visually examined to conclude favorable hinge binding forms.

\subsection{Chemistry Experimental Section}

\subsubsection{General Methods and Materials}

All chemicals were commercially available except those whose synthesis is described. Anhydrous $\mathrm{Na}_{2} \mathrm{SO}_{4}$ was used for drying organic extracts and all volatiles were removed under reduced pressure. 1,4-Dioxane was dried by refluxing over $\mathrm{CaH}_{2}$. All reaction mixtures and column eluents were monitored by TLC using commercial glass-backed thin layer chromatography (TLC) plates (Merck Kieselgel 60 F $_{254}$, Darmstadt, Germany) [75]. The plates were observed under UV light at 254 and $365 \mathrm{~nm}$. The technique of dry flash chromatography was used throughout for all non-TLC scale chromatographic separations using Merck Silica Gel 60 (less than $0.063 \mathrm{~mm}$ ). Melting points were determined using a PolyTherm-A, Wagner \& Munz, Koefler-Hotstage Microscope apparatus (Wagner \& Munz, 
Munich, Germany). Solvents used for recrystallization are indicated after the melting point. UV spectra were obtained using a Perkin-Elmer Lambda-25 UV/vis spectrophotometer (Perkin-Elmer, Waltham, MA, USA) and inflections are identified by the abbreviation "inf". IR spectra were recorded on a Shimadzu FTIR-NIR Prestige-21 spectrometer (Shimadzu, Kyoto, Japan) with Pike Miracle Ge ATR accessory (Pike Miracle, Madison, WI, USA) and strong, medium, and weak peaks are represented by s, $\mathrm{m}$, and $\mathrm{w}$, respectively. ${ }^{1} \mathrm{H}$ and ${ }^{13} \mathrm{C}$ NMR spectra were recorded on a Bruker Avance 300 (at 300 and $75 \mathrm{MHz}$, respectively), or a 500 machine (at 500 and $125 \mathrm{MHz}$, respectively, Bruker, Billerica, MA, USA, ${ }^{1} \mathrm{H}$ and ${ }^{13} \mathrm{C}$ NMR spectra of new compounds could be found from Supplementary Materials). Deuterated solvents were used for homonuclear lock and the signals are referenced to the deuterated solvent peaks. Attached proton test (APT) NMR studies were used for the assignment of the ${ }^{13} \mathrm{C}$ peaks as $\mathrm{CH}_{3}, \mathrm{CH}_{2}, \mathrm{CH}$, and $\mathrm{Cq}$ (quaternary). The Matrix-Assisted Laser Desorption/Ionization-Time of Flight (MALDI-TOF) mass spectra (+ve mode) were recorded on a Bruker Autoflex III Smartbeam instrument (Bruker, Leipzig, Germany), while ESI-APCI+ mass spectra were recorded on a Model 6110 Quadrupole MSD, Agilent Technologies (Agilent Technologies, Santa Clara, CA, USA). High resolution mass spectra were recorded in a ThermoFisher Q Exactive HF-X (ThermoFisher, Bremen, Germany) mass spectrometer coupled with a Waters Acquity H-class liquid chromatograph system. 3,5Dichloro-4H-1,2,6-thiadiazin-4-one (2) [18], 3-chloro-5-[(3-hydroxy-4-methylphenyl)amino]4H-1,2,6-thiadiazin-4-one (9) [15] and 3-chloro-5-morpholino-4H-1,2,6-thiadiazin-4-one (11) [29] were prepared according to the reported procedures.

\subsubsection{Preparation of 3-Aminosubstituted-4H-1,2,6-thiadiazines}

3-[(3-Acetylphenyl)amino]-5-chloro-4H-1,2,6-thiadiazin-4-one (6) (General procedure). To a stirred solution of 3,5-dichloro-4H-1,2,6-thiadiazin-4-one (2) (366 mg, $2 \mathrm{mmol}$ ) in EtOH $(4 \mathrm{~mL})$, at ca. $20^{\circ} \mathrm{C}$ was added 1-(3-aminophenyl)ethan-1-one $(135 \mathrm{mg}, 1 \mathrm{mmol})$ in one portion and the mixture stirred for $30 \mathrm{~min}$ at this temperature. Then, 2,6-lutidine ( $233 \mu \mathrm{L}$, $4 \mathrm{mmol}$ ) was added and the mixture was stirred at this temperature until complete consumption of the starting material (TLC, $2 \mathrm{~h}$ ). The yellow solid formed was then filtered under vacuum and washed with EtOH ( $2 \mathrm{~mL}), t$-BuOMe $(5 \mathrm{~mL})$, and $\mathrm{n}$-hexane $(5 \mathrm{~mL})$ to give the title compound $\mathbf{6}(190 \mathrm{mg}, 67 \%)$ as yellow needles, $\mathrm{mp} 201-202{ }^{\circ} \mathrm{C}$ (from EtOH/THF); $\mathrm{R}_{f} 0.41$ (DCM); (found: $\mathrm{C}, 46.70 ; \mathrm{H}, 2.97 ; \mathrm{N}, 14.73 . \mathrm{C}_{11} \mathrm{H}_{8} \mathrm{ClN}_{3} \mathrm{O}_{2} \mathrm{~S}$ requires $\mathrm{C}, 46.90 ; \mathrm{H}, 2.86$; $\mathrm{N}, 14.92 \%) ; \lambda_{\max }(\mathrm{DCM}) / \mathrm{nm} 295$ (log $\left.\varepsilon 4.12\right), 321$ (4.25), $334 \mathrm{inf}(4.18), 413$ (3.69); $v_{\max } / \mathrm{cm}^{-1}$ $3258 \mathrm{~m}(\mathrm{~N}-\mathrm{H}), 1680 \mathrm{~s}, 1632 \mathrm{~s}, 1589 \mathrm{~m}, 1547 \mathrm{~s}, 1518 \mathrm{~m}, 1487 \mathrm{w}, 1439 \mathrm{~m}, 1431 \mathrm{~s}, 1356 \mathrm{~m}, 1315 \mathrm{w}$, $1312 \mathrm{w}, 1287 \mathrm{~m}, 1260 \mathrm{~m}, 1240 \mathrm{~m}, 1177 \mathrm{~m}, 1169 \mathrm{~m}, 997 \mathrm{~m}, 908 \mathrm{~s}, 868 \mathrm{~m}, 810 \mathrm{~m}, 795 \mathrm{~m} ; \delta_{\mathrm{H}}(300 \mathrm{MHz}$ DMSO- $\left.d_{6}\right) 10.32(1 \mathrm{H}, \mathrm{s}, \mathrm{NH}), 8.39(1 \mathrm{H}, \mathrm{dd}, J 1.8,1.8, \mathrm{Ar} \mathrm{H}), 8.04(1 \mathrm{H}, \mathrm{ddd}, J$ 8.1, 2.2, 1.0, Ar H), $7.72\left(1 \mathrm{H}\right.$, ddd, J 7.7, 1.3, 1.1, Ar H), $7.51(1 \mathrm{H}, \mathrm{dd}, J$ 8.0, 8.0, $\mathrm{Ar} \mathrm{H}), 2.58\left(3 \mathrm{H}, \mathrm{s}, \mathrm{CH}_{3}\right)$; $\delta_{\mathrm{C}}\left(75 \mathrm{MHz}\right.$; DMSO-d $\left.d_{6}\right)$ 197.5 (Cq), 157.1 (Cq), $150.2(\mathrm{Cq}), 141.4(\mathrm{Cq}), 138.4(\mathrm{Cq}), 137.2(\mathrm{Cq})$, $129.0(\mathrm{CH}), 125.1(\mathrm{CH}), 123.9(\mathrm{CH}), 120.2(\mathrm{CH}), 26.7\left(\mathrm{CH}_{3}\right) ; \mathrm{m} / z$ (MALDI-TOF) $284\left(\mathrm{MH}^{+}+2\right.$, $39 \%), 282\left(\mathrm{MH}^{+}, 100\right), 265(37), 240(66)$.

3-Chloro-5-[(3-methoxyphenyl)amino]-4H-1,2,6-thiadiazin-4-one (7). Similar treatment of 3,5dichloro-4H-1,2,6-thiadiazin-4-one (2) (183 mg, $1 \mathrm{mmol}$ ) in EtOH ( $2 \mathrm{~mL}$ ), with 3-methoxyaniline $(246 \mathrm{mg}, 2 \mathrm{mmol}$ ) and 2,6-lutidine ( $116 \mu \mathrm{L}, 2 \mathrm{mmol}$ ) for $1 \mathrm{~h}$ gave the title compound 7 ( $494 \mathrm{mg}$, $92 \%$ ) as yellow plates, $\mathrm{mp} 176-177^{\circ} \mathrm{C}$ (from $\mathrm{PhH} / \mathrm{EtOH}$ ); $\mathrm{R}_{f} 0.54(\mathrm{DCM})$; (found: $\mathrm{C}, 44.45$; $\mathrm{H}, 2.97 ; \mathrm{N}, 15.56 . \mathrm{C}_{10} \mathrm{H}_{8} \mathrm{ClN}_{3} \mathrm{O}_{2} \mathrm{~S}$ requires $\left.\mathrm{C}, 44.53 ; \mathrm{H}, 2.99 ; \mathrm{N}, 15.58 \%\right) ; \lambda_{\max }(\mathrm{DCM}) / \mathrm{nm}$ $324(\log \varepsilon 4.61), 419$ (4.00); $v_{\max } / \mathrm{cm}^{-1} 3306 \mathrm{~m}(\mathrm{~N}-\mathrm{H}), 3067 \mathrm{w}$ (C-H ar), 2833 (C-H alip.), 1624s, $1613 \mathrm{~m}, 1609 \mathrm{~m}, 1589 \mathrm{~m}, 1566 \mathrm{~s}, 1514 \mathrm{w}, 1501 \mathrm{~m}, 1489 \mathrm{~m}, 1483 \mathrm{~m}, 1445 \mathrm{w}, 1435 \mathrm{~m}, 1427 \mathrm{~m}, 1321 \mathrm{~m}$, $1294 \mathrm{~m}, 1275 \mathrm{~m}, 1215 \mathrm{~m}, 1206 \mathrm{~m}, 1188 \mathrm{w}, 1175 \mathrm{w}, 1148 \mathrm{~s}, 1059 \mathrm{~s}, 1011 \mathrm{w}, 932 \mathrm{~m}, 874 \mathrm{~m}, 870 \mathrm{~m}, 831 \mathrm{~s}$, $772 \mathrm{~m}, 733 \mathrm{~m} ; \delta_{\mathrm{H}}\left(500 \mathrm{MHz} ; \mathrm{CDCl}_{3}\right) 8.66(1 \mathrm{H}$, br. s, NH) $7.31(1 \mathrm{H}, \mathrm{dd}, J 2.2,2.2, \mathrm{Ar} H), 7.29$ $(1 \mathrm{H}, \mathrm{d}, J$ J 8.2, $\mathrm{Ar} \mathrm{H}), 7.14(1 \mathrm{H}, \mathrm{dd}, J$ 8.0, 1.8, $\mathrm{Ar} \mathrm{H}), 6.74(1 \mathrm{H}, \mathrm{dd}, J$ 8.3 , 2.4, Ar H), $3.84(3 \mathrm{H}, \mathrm{s}$, $\left.\mathrm{CH}_{3}\right) ; \delta_{\mathrm{C}}\left(125 \mathrm{MHz} ; \mathrm{CDCl}_{3}\right) 160.3(\mathrm{Cq}), 156.6(\mathrm{Cq}), 149.7(\mathrm{Cq}), 142.0(\mathrm{Cq}), 137.9(\mathrm{Cq}), 130.0$ $(\mathrm{CH}), 112.2(\mathrm{CH}), 110.3(\mathrm{CH}), 105.9(\mathrm{CH}), 55.4\left(\mathrm{CH}_{3}\right) ; \mathrm{m} / z$ (MALDI-TOF) $272\left(\mathrm{MH}^{+}+2,39\right)$, $270\left(\mathrm{MH}^{+}, 79 \%\right), 234(100), 180(92)$. 
3-Chloro-5-[(3-hydroxyphenyl)amino]-4H-1,2,6-thiadiazin-4-one (8). Similar treatment of 3,5dichloro-4H-1,2,6-thiadiazin-4-one (2) (183 mg, $1 \mathrm{mmol})$ in EtOH (2 mL), with 2-aminophenol (109 $\mathrm{mg}, 1 \mathrm{mmol})$, and 2,6-lutidine $(116 \mu \mathrm{L}, 2 \mathrm{mmol})$ for $30 \mathrm{~min}$ gave the title compound 8 (228 mg, 89\%) as yellow needles, $\mathrm{mp} 204-205{ }^{\circ} \mathrm{C}$ (from $\left.\mathrm{PhH} / \mathrm{THF}\right) ; \mathrm{R}_{f} 0.25$ (DCM); (found: $\mathrm{C}, 42.11 ; \mathrm{H}, 2.46 ; \mathrm{N}, 16.24 . \mathrm{C}_{9} \mathrm{H}_{6} \mathrm{ClN}_{3} \mathrm{O}_{2} \mathrm{~S}$ requires $\mathrm{C}, 42.28 ; \mathrm{H}, 2.37 ; \mathrm{N}, 16.44 \%$ ); $\lambda_{\max }(\mathrm{DCM}) / \mathrm{nm} 259$ (log ع 3.78), $288 \inf (4.40), 323$ (4.23), 417 (4.03); $v_{\max } / \mathrm{cm}^{-1} 3379 \mathrm{br}$ (O-H), $3256(\mathrm{~N}-\mathrm{H}), 1640 \mathrm{~m}, 1599 \mathrm{~s}, 1560 \mathrm{~m}, 1551 \mathrm{~s}, 1524 \mathrm{~m}, 1466 \mathrm{~m}, 1451 \mathrm{~m}, 1439 \mathrm{~m}, 1321 \mathrm{w}$, $1304 \mathrm{~m}, 1277 \mathrm{~m}, 1227 \mathrm{w}, 1148 \mathrm{~m}, 1092 \mathrm{w}, 972 \mathrm{~m}, 870 \mathrm{~m}, 860 \mathrm{~m}, 841 \mathrm{~m}, 783 \mathrm{~m}, 739 \mathrm{~m}, 731 \mathrm{~m}$; $\delta_{\mathrm{H}}\left(300 \mathrm{MHz}\right.$; DMSO- $\left.d_{6}\right) 9.96(1 \mathrm{H}, \mathrm{s}), 9.52(1 \mathrm{H}$, br. s), $7.28(1 \mathrm{H}, \mathrm{dd}, J$ 2,1, 2.1, Ar H), 7.17 $(1 \mathrm{H}, \mathrm{dd}, J$ 7.7, 1.3, Ar H), $7.12(1 \mathrm{H}, \mathrm{dd}, J$ 8.0, 8.0, Ar H), $6.53(1 \mathrm{H}$, ddd, J 7.7, 2.2, 1.3, Ar H); $\delta_{\mathrm{C}}\left(125 \mathrm{MHz}\right.$; DMSO-d $\left.d_{6}\right) 157.4(\mathrm{Cq}), 157.1(\mathrm{Cq}), 150.0(\mathrm{Cq}), 141.0(\mathrm{Cq}), 138.8(\mathrm{Cq}), 129.2(\mathrm{CH})$, $111.7(\mathrm{CH}), 111.2(\mathrm{CH}), 107.7(\mathrm{CH}) ; m / z$ (MALDI-TOF) $258\left(\mathrm{MH}^{+}+2,32\right), 256\left(\mathrm{MH}^{+}, 100 \%\right)$, 238 (56), 220 (45), 166 (32).

3-Chloro-5-[(5-hydroxy-2-methylphenyl)amino]-4H-1,2,6-thiadiazin-4-one (10). Similar treatment of 3,5-dichloro-4H-1,2,6-thiadiazin-4-one (2) (183 mg, $1 \mathrm{mmol})$ in EtOH (2 mL), with 3-amino-4-methylphenol (123 mg, $1 \mathrm{mmol})$ and 2,6-lutidine $(116 \mu \mathrm{L}, 2 \mathrm{mmol})$ for $1 \mathrm{~h}$ gave the title compound $10(262 \mathrm{mg}, 97 \%)$ as yellow needles, $\mathrm{mp} 191-192{ }^{\circ} \mathrm{C}$ (from $\mathrm{PhH} / \mathrm{c}$-hexane); $\mathrm{R}_{f} 0.18$ (DCM); (found: $\mathrm{C}, 44.59 ; \mathrm{H}, 2.91 ; \mathrm{N}, 15.66 . \mathrm{C}_{10} \mathrm{H}_{8} \mathrm{ClN}_{3} \mathrm{O}_{2} \mathrm{~S}$ requires $\mathrm{C}, 44.53 ; \mathrm{H}, 2.99$; $\mathrm{N}, 15.58 \%) ; \lambda_{\max }(\mathrm{DCM}) / \mathrm{nm} 319\left(\log \varepsilon\right.$ 4.27), 398 (3.73); $v_{\max } / \mathrm{cm}^{-1} 3420 \mathrm{br}(\mathrm{O}-\mathrm{H}), 3364$ $(\mathrm{N}-\mathrm{H}), 1620 \mathrm{~m}, 1609 \mathrm{~m}, 1551 \mathrm{~s}, 1518 \mathrm{~m}, 1514 \mathrm{~m}, 1466 \mathrm{~m}, 1462 \mathrm{~m}, 1445 \mathrm{~m}, 1356 \mathrm{~m}, 1267 \mathrm{~m}, 1217 \mathrm{~m}$, $1153 \mathrm{~m}, 1105 \mathrm{~m}, 1015 \mathrm{~m}, 1005 \mathrm{~m}, 974 \mathrm{~m}, 864 \mathrm{~m}, 847 \mathrm{~m}, 810 \mathrm{~m}, 737 \mathrm{~m} ; \delta_{\mathrm{H}}\left(500 \mathrm{MHz} ; \mathrm{DMSO}-d_{6}\right)$ $9.52(1 \mathrm{H}, \mathrm{s}), 9.33(1 \mathrm{H}, \mathrm{s}), 7.04(1 \mathrm{H}, \mathrm{d}, J$ 8.3, $\operatorname{Ar} H), 6.90(1 \mathrm{H}, \mathrm{d}, J$ 2.5, Ar H), $6.58(1 \mathrm{H}, \mathrm{dd}$, J 8.2, 2.5, $\mathrm{Ar} H), 2.09\left(3 \mathrm{H}, \mathrm{s}, \mathrm{CH}_{3}\right) ; \delta_{\mathrm{C}}(125 \mathrm{MHz}$; DMSO-d 6 ) $157.0(\mathrm{Cq}), 155.5(\mathrm{Cq}), 151.4$ (Cq), $140.4(\mathrm{Cq}), 135.9(\mathrm{Cq}), 130.9(\mathrm{CH}), 122.6(\mathrm{Cq}), 113.1(\mathrm{CH}), 111.9(\mathrm{CH}), 16.6\left(\mathrm{CH}_{3}\right) ; \mathrm{m} / \mathrm{z}$ (MALDI-TOF) $272\left(\mathrm{MH}^{+}+2,70 \%\right), 270\left(\mathrm{MH}^{+}, 100\right), 252$ (96), 234 (55), 211 (34), 180 (37).

3-Chloro-5-(4-methylpiperazin-1-yl)-4H-1,2,6-thiadiazin-4-one (12). Similar treatment of 3,5-dichloro$4 H-1,2,6$-thiadiazin-4-one (2) (183 mg, $1 \mathrm{mmol})$ in EtOH (2 mL), with $N$-methylpiperazine $(215 \mu \mathrm{L}$, $2 \mathrm{mmol}$ ) for $30 \mathrm{~min}$ gave the title compound $12(245 \mathrm{mg}, 99 \%)$ as yellow needles, $\mathrm{mp}$ $76-77^{\circ} \mathrm{C}$ (from $c$-hexane); $\mathrm{R}_{f} 0.29$ (DCM/t-BuOMe, 50:50); (found: $\mathrm{C}, 38.72 ; \mathrm{H}, 4.66 ; \mathrm{N}$, 22.53. $\mathrm{C}_{8} \mathrm{H}_{11} \mathrm{ClN}_{4} \mathrm{OS}$ requires $\left.\mathrm{C}, 38.95 ; \mathrm{H}, 4.49 ; \mathrm{N}, 22.71 \%\right) ; \lambda_{\max }(\mathrm{DCM}) / \mathrm{nm} 269(\log \varepsilon 3.78)$, 312 (4.15), $320 \inf (4.18), 406$ (3.78); $v_{\max } / \mathrm{cm}^{-1} 2965 \mathrm{w}, 2934 \mathrm{w}, 2845 \mathrm{w}$ and $2804 \mathrm{w}$ (C-H), $1624 \mathrm{~s}, 1493 \mathrm{~m}, 1445 \mathrm{~m}, 1433 \mathrm{~m}, 1402 \mathrm{~m}, 1356 \mathrm{~m}, 1335 \mathrm{w}, 1306 \mathrm{~m}, 1288 \mathrm{~m}, 1271 \mathrm{~m}, 1196 \mathrm{~m}, 1159 \mathrm{~m}$, $1144 \mathrm{~m}, 1080 \mathrm{~m}, 1059 \mathrm{~m}, 1005 \mathrm{~m}, 984 \mathrm{~m}, 939 \mathrm{~m}, 864 \mathrm{~m}, 854 \mathrm{~m}, 843 \mathrm{~m}, 791 \mathrm{~m}, 775 \mathrm{~m}, 760 \mathrm{~m}, 727 \mathrm{~m}$; $\delta_{\mathrm{H}}\left(500 \mathrm{MHz} ; \mathrm{CDCl}_{3}\right) 3.92\left(4 \mathrm{H}\right.$, br. s, $\left.\mathrm{CH}_{2}\right), 2.51\left(4 \mathrm{H}, \mathrm{t}, J\right.$ 5.1, $\left.\mathrm{CH}_{2}\right), 2.32\left(3 \mathrm{H}, \mathrm{s}, \mathrm{CH}_{3}\right)$; $\delta_{\mathrm{C}}\left(125 \mathrm{MHz} ; \mathrm{CDCl}_{3}\right) 158.7(\mathrm{Cq}), 152.9(\mathrm{Cq}), 145.2(\mathrm{Cq}), 54.8\left(\mathrm{CH}_{2}\right), 46.6\left(\mathrm{CH}_{2}\right), 45.9\left(\mathrm{CH}_{3}\right)$; $\mathrm{m} / z(\mathrm{ESI}+) 249\left(\mathrm{MH}^{+}+2,37 \%\right), 247\left(\mathrm{MH}^{+}, 100\right), 130(82)$.

5-Chloro-3-[(1H-indazol-5-yl)amino]-4H-1,2,6-thiadiazin-4-one (13). Similar treatment of 3,5dichloro-4H-1,2,6-thiadiazin-4-one (2) $(183 \mathrm{mg}, 1 \mathrm{mmol})$ in EtOH $(2 \mathrm{~mL})$, with $1 \mathrm{H}$-indazol5-amine (133 mg, $1 \mathrm{mmol})$ and 2,6-lutidine $(116 \mu \mathrm{L}, 2 \mathrm{mmol})$ for $1 \mathrm{~h}$ gave the title compound 13 (255 mg, 91\%) as orange plates, $\mathrm{mp} 290-291{ }^{\circ} \mathrm{C}$ (from PhMe/THF); $\mathrm{R}_{f} 0.53$ (DCM/tBuOMe, 80:20); (found: $\mathrm{C}, 42.82 ; \mathrm{H}, 2.09 ; \mathrm{N}, 24.91 . \mathrm{C}_{10} \mathrm{H}_{6} \mathrm{ClN}_{5} \mathrm{OS}$ requires $\mathrm{C}, 42.94 ; \mathrm{H}$, 2.16; N, 25.04\%); $\lambda_{\max }(\mathrm{THF}) / \mathrm{nm} 254$ (log $\varepsilon$ 4.57), 286 (4.59), 325 (4.40), 338 (4.38), 423 (3.77); $v_{\max } / \mathrm{cm}^{-1} 3393 \mathrm{~m}(\mathrm{~N}-\mathrm{H}), 3213 \mathrm{w}$ and $3086 \mathrm{w}(\mathrm{C}-\mathrm{H}), 1626 \mathrm{~m}, 1589 \mathrm{~m}, 1576 \mathrm{w}, 1562 \mathrm{~m}$, $1557 \mathrm{~m}, 1508 \mathrm{~s}, 1504 \mathrm{~m}, 1427 \mathrm{~m}, 1281 \mathrm{~m}, 1198 \mathrm{~m}, 1138 \mathrm{~m}, 961 \mathrm{w}, 937 \mathrm{~s}, 872 \mathrm{~s}, 841 \mathrm{w}, 808 \mathrm{~m}, 754 \mathrm{~m}$; $\delta_{\mathrm{H}}\left(500 \mathrm{MHz}\right.$; DMSO-d $\left.d_{6}\right) 13.06(1 \mathrm{H}, \mathrm{s}, \mathrm{NH}), 10.18(1 \mathrm{H}, \mathrm{s}, \mathrm{NH}), 8.18(1 \mathrm{H}, \mathrm{s}, \mathrm{Ar} H), 8.07(1 \mathrm{H}, \mathrm{s}$, $\operatorname{Ar} H), 7.65(1 \mathrm{H}, \mathrm{d}, J 7.5, \mathrm{Ar} H), 7.52(1 \mathrm{H}, \mathrm{d}, J 7.5, \mathrm{Ar} H) ; \delta_{\mathrm{C}}(125 \mathrm{MHz}$; DMSO-d 6$) 157.1(\mathrm{Cq})$, $150.5(\mathrm{Cq}), 140.5(\mathrm{Cq}), 137.2(\mathrm{Cq}), 133.5(\mathrm{CH}), 130.6(\mathrm{Cq}), 122.5(\mathrm{Cq}), 122.0(\mathrm{CH}), 111.7(\mathrm{CH})$, $110.1(\mathrm{CH}) ; m / z$ (MALDI-TOF) $282\left(\mathrm{MH}^{+}+2,33 \%\right), 280\left(\mathrm{MH}^{+}, 100\right), 244$ (44), 190 (50).

\subsubsection{Preparation of 5-Amino-Substituted 3-Arylthiadiazinones}

3-[(3-Acetylphenyl)amino]-5-(1H-pyrrolo[2,3-b]pyridin-4-yl)-4H-1,2,6-thiadiazin-4-one (14). Similar treatment of 3-[(3-acetylphenyl)amino]-5-chloro-4H-1,2,6-thiadiazin-4-one (6) (56.3 mg, 
$0.20 \mathrm{mmol}$ ) with (1H-pyrrolo[2,3-b]pyridin-4-yl)boronic acid $(40.8 \mathrm{mg}, 0.22 \mathrm{mmol})$ for $18 \mathrm{~h}$ gave the title compound $14\left(35.5 \mathrm{mg}, 49 \%\right.$ ) as yellow needles, $\mathrm{mp} 271-273{ }^{\circ} \mathrm{C}$ (from $\mathrm{EtOH} / \mathrm{PhH}$ ); $\mathrm{R}_{f} 0.46$ (DCM/Et $t_{2} \mathrm{O}, 50: 50$ ); (found: $\mathrm{C}, 59.25 ; \mathrm{H}, 3.72 ; \mathrm{N}, 19.06 . \mathrm{C}_{18} \mathrm{H}_{13} \mathrm{~N}_{5} \mathrm{O}_{2} \mathrm{~S}$ requires $\mathrm{C}, 59.49 ; \mathrm{H}, 3.61 ; \mathrm{N}, 19.27 \%) ; \lambda_{\max }(\mathrm{THF}) / \mathrm{nm} 290$ (log $\left.\varepsilon 4.00\right), 360$ (4.40), $415 \mathrm{inf}$ (4.18); $v_{\max } / \mathrm{cm}^{-1} 3148 \mathrm{w}, 2916 \mathrm{w}, 1672 \mathrm{~m}, 1612 \mathrm{~m}, 1583 \mathrm{~m}, 1451 \mathrm{~s}, 1535 \mathrm{~s}, 1483 \mathrm{w}, 1443 \mathrm{~m}, 1429 \mathrm{w}$, $1323 \mathrm{~m}, 1287 \mathrm{w}, 1265 \mathrm{~s}, 1223 \mathrm{~m}, 953 \mathrm{~m}, 908 \mathrm{~m}, 898 \mathrm{~m}, 878 \mathrm{~m}, 851 \mathrm{~m}, 843 \mathrm{~m}, 833 \mathrm{~m}, 825 \mathrm{~m}, 816 \mathrm{~m}$, $783 \mathrm{~m}, 768 \mathrm{~m}, 739 \mathrm{~m}, 723 \mathrm{~m}, 704 \mathrm{~m} ; \delta_{\mathrm{H}}\left(500 \mathrm{MHz} ; \mathrm{DMSO}-d_{6}\right) 11.80(1 \mathrm{H}, \mathrm{s}), 10.39(1 \mathrm{H}, \mathrm{s}), 8.47$ $(1 \mathrm{H}, \mathrm{dd}, J$ J 1.8, 1.8, $\mathrm{Ar} H), 8.33(1 \mathrm{H}, \mathrm{d}, J 5.1, \mathrm{Ar} H), 8.12(1 \mathrm{H}, \mathrm{dd}, J$ 8.0, 1.1, $\mathrm{Ar} H), 7.75(1 \mathrm{H}, \mathrm{d}$, J 5.0, Ar H), 7.73 (1H, d, J 1.1, Ar H), 7.57-7.52 (2H, m, Ar H), $6.77(1 \mathrm{H}, \mathrm{dd}, J 3.3,1.9, \mathrm{Ar}$ $H) ; \delta_{\mathrm{C}}(75 \mathrm{MHz}$; DMSO-d 6 ) $159.3(\mathrm{Cq}), 152.4(\mathrm{Cq}), 151.9(\mathrm{Cq}), 149.4(\mathrm{Cq}), 141.8(\mathrm{CH}), 138.4$ (Cq), $137.2(\mathrm{Cq}), 133.6(\mathrm{Cq}), 129.0(\mathrm{CH}), 126.9(\mathrm{CH}), 125.2(\mathrm{CH}), 123.7(\mathrm{CH}), 120.3(\mathrm{CH}), 116.9$ (Cq), $114.8(\mathrm{CH}), 100.8(\mathrm{CH}), 26.7\left(\mathrm{CH}_{3}\right) ; \mathrm{m} / z(\mathrm{ESI}+) 363\left(\mathrm{M}^{+}, 56 \%\right), 362\left(\mathrm{M}^{+}-\mathrm{H}, 100\right), 350$ (62); HRMS (ESI+) found for $\mathrm{MH}^{+} 364.08444, \mathrm{C}_{18} \mathrm{H}_{14} \mathrm{~N}_{5} \mathrm{O}_{2} \mathrm{~S}^{+}$requires 364.08682 .

3-[(3-Methoxyphenyl)amino]-5-(1H-pyrrolo[2,3-b]pyridin-4-yl)-4H-1,2,6-thiadiazin-4-one (15) (General procedure A). To a mixture of 3-chloro-5-[(3-methoxyphenyl)amino]-4H-1,2,6-thiadiazin4-one (7) (53.9 mg, $0.20 \mathrm{mmol}),(1 \mathrm{H}$-pyrrolo[2,3-b]pyridin-4-yl)boronic acid ( $35.7 \mathrm{mg}, 0.22 \mathrm{mmol}$ ), $\mathrm{Pd}\left[3,5-\left(\mathrm{F}_{3} \mathrm{C}\right)_{2} \mathrm{C}_{6} \mathrm{H}_{3}\right]_{3}(21.2 \mathrm{mg}, 5 \mathrm{~mol} \%)$, DPEPhos ( $\left.5.3 \mathrm{mg}, 5 \mathrm{~mol} \%\right)$ and powdered dry $\mathrm{K}_{2} \mathrm{CO}_{3}(66.4 \mathrm{mg}, 0.48 \mathrm{mmol})$ was added dioxane $(2 \mathrm{~mL})$ and $\mathrm{H}_{2} \mathrm{O}(0.3 \mathrm{~mL})$. The stirred suspension was then deaerated by bubbling of Ar through it for $5 \mathrm{~min}$ and then heated at reflux under Ar until complete consumption of the starting thiadiazine (TLC, $20 \mathrm{~h}$ ). The mixture was cooled to ca. $20{ }^{\circ} \mathrm{C}$, then filtered and washed with $\mathrm{H}_{2} \mathrm{O}(5 \mathrm{~mL})$ and $\mathrm{EtOH}$ $(5 \mathrm{~mL})$ and dried under vacuum to give the title compound $15(58.4 \mathrm{mg}, 83 \%)$ as orange needles, $\mathrm{mp} 257-258^{\circ} \mathrm{C}$ (from $c$-hexane); $\mathrm{R}_{f} 0.59$ (DCM/t-BuOMe, 80:20); (found: $\mathrm{C}, 58.12$; $\mathrm{H}, 3.67 ; \mathrm{N}, 19.85 . \mathrm{C}_{17} \mathrm{H}_{13} \mathrm{~N}_{5} \mathrm{O}_{2} \mathrm{~S}$ requires $\left.\mathrm{C}, 58.11 ; \mathrm{H}, 3.73 ; \mathrm{N}, 19.93 \%\right) ; \lambda_{\max }(\mathrm{THF}) / \mathrm{nm} 360$ (log $\varepsilon 4.05), 422 \inf (3.79) ; v_{\max } / \mathrm{cm}^{-1} 3136 \mathrm{w}(\mathrm{C}-\mathrm{H}), 1613 \mathrm{~m}, 1605 \mathrm{~m}, 1587 \mathrm{~m}, 1541 \mathrm{~m}, 1534 \mathrm{~s}$, $1531 \mathrm{~s}, 1483 \mathrm{~m}, 1462 \mathrm{~m}, 1327 \mathrm{~m}, 1288 \mathrm{~m}, 1240 \mathrm{w}, 1223 \mathrm{~m}, 1211 \mathrm{~m}, 1155 \mathrm{~s}, 1092 \mathrm{w}, 1049 \mathrm{~m}, 966 \mathrm{w}$, $897 \mathrm{~m}, 872 \mathrm{w}, 792 \mathrm{~m}, 777 \mathrm{~m}, 768 \mathrm{~m}, 760 \mathrm{~m}, 718 \mathrm{~m} ; \delta_{\mathrm{H}}\left(500 \mathrm{MHz}\right.$; DMSO- $\left.d_{6}\right) 11.79(1 \mathrm{H}, \mathrm{br}, \mathrm{NH})$, $10.14(1 \mathrm{H}, \mathrm{s}, \mathrm{NH}), 8.32(1 \mathrm{H}, \mathrm{d}, J 5.0, \mathrm{Ar} H), 7.38(1 \mathrm{H}, \mathrm{dd}, J 5.0, \operatorname{Ar} H), 7.57-7.48(3 \mathrm{H}, \mathrm{m}, \mathrm{Ar}$ H), $7.28(1 \mathrm{H}, \mathrm{dd}, J$ 8.2, 8.2, $\operatorname{Ar} H), 6.76(1 \mathrm{H}, \mathrm{d}, J$ J.0, 1.7, $\operatorname{Ar} H), 6.72(1 \mathrm{H}, \mathrm{dd}, J$ 8.1, 1.7, $\operatorname{Ar} H)$, $3.77\left(3 \mathrm{H}, \mathrm{s}, \mathrm{CH}_{3}\right) ; \delta_{\mathrm{C}}(75 \mathrm{MHz}$; DMSO-d 6 ) $159.4(\mathrm{Cq}), 159.3(\mathrm{Cq}), 152.3(\mathrm{Cq}), 151.6(\mathrm{Cq}), 149.4$ $(\mathrm{Cq}), 141.8(\mathrm{CH}), 139.1(\mathrm{Cq}), 133.7(\mathrm{Cq}), 129.4(\mathrm{CH}), 129.9(\mathrm{CH}), 116.9(\mathrm{Cq}), 114.8(\mathrm{CH}), 112.9$ $(\mathrm{CH}), 109.3(\mathrm{CH}), 106.6(\mathrm{CH}), 100.9(\mathrm{CH}), 55.0\left(\mathrm{CH}_{3}\right) ; \mathrm{m} / z$ (MALDI-TOF) $352\left(\mathrm{MH}^{+}, 100 \%\right)$, $351\left(\mathrm{M}^{+}, 35\right)$; HRMS (ESI+) found for $\mathrm{MH}^{+} 352.08567, \mathrm{C}_{17} \mathrm{H}_{14} \mathrm{~N}_{5} \mathrm{O}_{2} \mathrm{~S}^{+}$requires 352.08682 .

3-[(3-Hydroxyphenyl)amino]-5-(1H-pyrrolo[2,3-b]pyridin-4-yl)-4H-1,2,6-thiadiazin-4-one (16). Similar treatment of 3-chloro-5-[(3-hydroxy-4-methylphenyl)amino]-4H-1,2,6-thiadiazin-4-one (8) $(53.9 \mathrm{mg}, 0.20 \mathrm{mmol})$ with (1H-pyrrolo[2,3-b]pyridin-4-yl)boronic acid $(40.3 \mathrm{mg}, 0.22 \mathrm{mmol})$ for $24 \mathrm{~h}$ gave after chromatography (DCM/t-BuOMe, 50:50) the title compound 16 (24.2 mg, $36 \%$ ) as yellow plates, $\mathrm{mp} 326-327^{\circ} \mathrm{C}$ (from $\mathrm{PhH}$ ); $\mathrm{R}_{f} 0.56$ (DCM/t-BuOMe, 50:50); (found: $\mathrm{C}, 57.14 ; \mathrm{H}, 3.22 ; \mathrm{N}, 20.52 . \mathrm{C}_{16} \mathrm{H}_{11} \mathrm{~N}_{5} \mathrm{O}_{2} \mathrm{~S}$ requires $\left.\mathrm{C}, 56.97 ; \mathrm{H}, 3.29 ; \mathrm{N}, 20.76 \%\right) ; \lambda_{\max }(\mathrm{THF}) /$ $\mathrm{nm} 366(\log \varepsilon 4.33), 423 \inf (4.07) ; v_{\max } / \mathrm{cm}^{-1} 3401 \mathrm{w}$ and $3331 \mathrm{w}(\mathrm{N}-\mathrm{H}), 1612 \mathrm{~m}, 1591 \mathrm{~s}, 1587 \mathrm{~s}$, $1543 \mathrm{~s}, 1503 \mathrm{~m}, 1381 \mathrm{w}, 1332 \mathrm{~m}, 1269 \mathrm{w}, 1204 \mathrm{~m}, 1167 \mathrm{~m}, 1153 \mathrm{~m}, 989 \mathrm{~m}, 793 \mathrm{~m}, 789 \mathrm{~m}, 770 \mathrm{~m}, 727 \mathrm{~m}$, $716 \mathrm{~m} ; \delta_{\mathrm{H}}\left(500 \mathrm{MHz} ; \mathrm{DMSO}-d_{6}\right) 11.79(1 \mathrm{H}, \mathrm{s}), 10.03(1 \mathrm{H}, \mathrm{s}), 9.48(1 \mathrm{H}, \mathrm{s}), 8.31(1 \mathrm{H}, \mathrm{d}, J$ J 5.0, $\operatorname{Ar} H), 7.74(1 \mathrm{H}, \mathrm{d}, J 5.0, \operatorname{Ar} H), 7.55(1 \mathrm{H}, \mathrm{dd}, J$ 2.9, 2.9, Ar H), $7.39(1 \mathrm{H}, \mathrm{dd}, J 1.9,1.9, \operatorname{Ar} H)$, $7.25(1 \mathrm{H}, \mathrm{d}, J$ J 8.0, Ar H), 7.15 (1H, dd, J 8.0, 8.0, Ar H), 6.76 (1H, dd, J 3.2, 1.9, Ar H), 6.55 $\left(1 \mathrm{H}, \mathrm{dd}, J\right.$ 8.0, 1.7, Ar H); $\delta_{\mathrm{C}}\left(75 \mathrm{MHz}\right.$; DMSO-d $\left.\mathrm{d}_{6}\right) 159.3(\mathrm{Cq}), 157.5(\mathrm{Cq}), 152.2(\mathrm{Cq}), 151.5$ $(\mathrm{Cq}), 149.4(\mathrm{Cq}), 141.8(\mathrm{CH}), 138.9(\mathrm{Cq}), 133.7(\mathrm{Cq}), 129.2(\mathrm{CH}), 126.9(\mathrm{CH}), 116.9(\mathrm{Cq}), 114.8$ $(\mathrm{CH}), 111.7(\mathrm{CH}), 107.7(\mathrm{CH}), 100.9(\mathrm{CH}) ; \mathrm{m} / z$ (MALDI-TOF) $338\left(\mathrm{MH}^{+}, 100 \%\right), 337\left(\mathrm{M}^{+}\right.$, 67); HRMS (ESI+) found for $\mathrm{MH}^{+} 338.06991, \mathrm{C}_{16} \mathrm{H}_{12} \mathrm{~N}_{5} \mathrm{O}_{2} \mathrm{~S}^{+}$requires 338.07117.

3-[(3-Hydroxy-4-methylphenyl)amino]-5-(1H-pyrrolo[2,3-b]pyridin-4-yl)-4H-1,2,6-thiadiazin-4-one (17). Similar treatment of 3-chloro-5-[(3-hydroxy-4-methylphenyl)amino]-4H-1,2,6-thiadiazin4-one (9) $(53.9 \mathrm{mg}, 0.20 \mathrm{mmol})$ with (1H-pyrrolo[2,3-b]pyridin-4-yl)boronic acid $(30.0 \mathrm{mg}$, $0.22 \mathrm{mmol}$ ) for $2 \mathrm{~h}$ gave after chromatography (DCM/ $\left.\mathrm{Et}_{2} \mathrm{O} / \mathrm{THF}, 50: 40: 10\right)$ the title compound $\mathbf{1 7}\left(51.4 \mathrm{mg}, 73 \%\right.$ ) as yellow needles, mp $292-293{ }^{\circ} \mathrm{C}$ (from $\left.\mathrm{PhH}\right) ; \mathrm{R}_{f} 0.61\left(\mathrm{DCM} / \mathrm{Et}_{2} \mathrm{O} /\right.$ 
THF, 50:40:10); (found: $\mathrm{C}, 58.12 ; \mathrm{H}, 3.67 ; \mathrm{N}, 19.85 . \mathrm{C}_{17} \mathrm{H}_{13} \mathrm{~N}_{5} \mathrm{O}_{2} \mathrm{~S}$ requires $\mathrm{C}, 58.11 ; \mathrm{H}, 3.73 ; \mathrm{N}$, $19.93 \%) ; \lambda_{\max }(\mathrm{THF}) / \mathrm{nm} 295$ (log ع 3.75), 366 (4.00), $430 \mathrm{inf}(3.68) ; v_{\max } / \mathrm{cm}^{-1} 3298 \mathrm{w}, 3138 \mathrm{w}$, $2882 \mathrm{w}, 1614 \mathrm{~m}, 1597 \mathrm{~m}, 1591 \mathrm{~m}, 1535 \mathrm{~s}, 1503 \mathrm{~m}, 1422 \mathrm{~m}, 1277 \mathrm{w}, 1260 \mathrm{w}, 1231 \mathrm{w}, 1219 \mathrm{w}, 1207 \mathrm{w}$, $1186 \mathrm{w}, 1159 \mathrm{w}, 1155 \mathrm{w}, 1128 \mathrm{w}, 1111 \mathrm{~m}, 995 \mathrm{~m}, 899 \mathrm{~m}, 856 \mathrm{~m}, 789 \mathrm{~m}, 729 \mathrm{~m}, 718 \mathrm{~s} ; \delta_{\mathrm{H}}(300 \mathrm{MHz}$; DMSO-d $) 11.79(1 \mathrm{H}$, br s), $9.98(1 \mathrm{H}, \mathrm{s}), 9.39(1 \mathrm{H}, \mathrm{s}), 8.31(1 \mathrm{H}, \mathrm{d}, J 5.0, \mathrm{Ar} \mathrm{H}), 7.74(1 \mathrm{H}, \mathrm{d}$, $J$ 5.0, Ar H), $7.55(1 \mathrm{H}, \mathrm{dd}, J$ 2.8, 2.8, Ar H), $7.42(1 \mathrm{H}, \mathrm{d}, J 1.9, \mathrm{Ar} H), 7.13$ (1H, dd, J 8.2, 1.9, Ar H), $7.03\left(1 \mathrm{H}, \mathrm{d}, J\right.$ 8.0, Ar H), $6.76(1 \mathrm{H}, \mathrm{dd}, J 3.3,1.9, \mathrm{Ar} \mathrm{H}), 2.10\left(3 \mathrm{H} . \mathrm{s}, \mathrm{CH}_{3}\right) ; \delta_{\mathrm{C}}(75 \mathrm{MHz}$; DMSO-d 6$) 159.3(\mathrm{Cq}), 155.1(\mathrm{Cq}), 152.2(\mathrm{Cq}), 151.2(\mathrm{Cq}), 149.4(\mathrm{Cq}), 141.7(\mathrm{CH}), 136.3(\mathrm{Cq})$, $133.8(\mathrm{Cq}), 130.2(\mathrm{CH}), 126.8(\mathrm{CH}), 119.8(\mathrm{Cq}), 116.9(\mathrm{Cq}), 114.8(\mathrm{CH}), 111.8(\mathrm{CH}), 107.3(\mathrm{CH})$, $100.9(\mathrm{CH}), 15.5\left(\mathrm{CH}_{3}\right) ; m / z$ (MALDI-TOF) $352\left(\mathrm{MH}^{+}, 90 \%\right), 351\left(\mathrm{M}^{+}, 100\right)$; HRMS (ESI+) found for $\mathrm{MH}^{+} 352.08558, \mathrm{C}_{17} \mathrm{H}_{14} \mathrm{~N}_{5} \mathrm{O}_{2} \mathrm{~S}^{+}$requires 352.08682 .

3-[(5-Hydroxy-2-methylphenyl)amino]-5-(1H-pyrrolo[2,3-b]pyridin-4-yl)-4H-1,2,6-thiadiazin-4-one (18). Similar treatment of 2-[(5-chloro-4-oxo-4H-1,2,6-thiadiazin-3-yl)amino]-N-methylbenzamide (10) (59.3 mg, $0.20 \mathrm{mmol}$ ) with (1H-pyrrolo[2,3-b]pyridin-4-yl)boronic acid (39.2 mg, $0.22 \mathrm{mmol})$ for $3 \mathrm{~h}$ gave after chromatography $\left(\mathrm{DCM} / \mathrm{Et}_{2} \mathrm{O}, 50: 50\right)$ the title compound $18(39.1 \mathrm{mg}, 56 \%)$ as yellow needles, $\mathrm{mp} 304-305^{\circ} \mathrm{C}$ (from PhH); $\mathrm{R}_{f} 0.63$ (DCM/Et $\mathrm{DC}_{2} \mathrm{O}$ 50:50); (found: C, 58.36; $\mathrm{H}, 3.69 ; \mathrm{N}, 19.74 . \mathrm{C}_{17} \mathrm{H}_{13} \mathrm{~N}_{5} \mathrm{O}_{2} \mathrm{~S}$ requires $\left.\mathrm{C}, 58.11 ; \mathrm{H}, 3.73 ; \mathrm{N}, 19.93 \%\right) ; \lambda_{\max }(\mathrm{THF}) / \mathrm{nm} 292$ ( $\log \varepsilon$ 3.34), 364 (3.60), $420 \inf$ (3.37); $v_{\max } / \mathrm{cm}^{-1} 3339 \mathrm{w}, 3102 \mathrm{w}, 2880 \mathrm{w}, 1612 \mathrm{~m}, 1587 \mathrm{~m}, 1541 \mathrm{~s}$, 1537s, 1481m, 1477m, 1381w, 1321m, 1287w, 1221w, 1204w, 1155m, 1130w, 1115w, 1007m, $982 \mathrm{~m}, 899 \mathrm{~m}, 866 \mathrm{~m}, 812 \mathrm{~m}, 808 \mathrm{~m}, 797 \mathrm{~m}, 791 \mathrm{~m}, 764 \mathrm{~m}, 731 \mathrm{~m}, 727 \mathrm{~m}, 716 \mathrm{~m} ; \delta_{\mathrm{H}}(300 \mathrm{MHz}$; DMSO-d $) 11.79(1 \mathrm{H}$, br s), $9.58(1 \mathrm{H}, \mathrm{s}), 9.34(1 \mathrm{H}, \mathrm{s}), 8.31(1 \mathrm{H}, \mathrm{d}, J 5.0, \mathrm{Ar} \mathrm{H}), 7.80(1 \mathrm{H}, \mathrm{d}$, $J$ 5.1, Ar H), $7.56(1 \mathrm{H}, \mathrm{dd}, J 3.0,3.0, \operatorname{Ar} H), 7.12(1 \mathrm{H}, \mathrm{d}, J 2.5, \operatorname{Ar} H), 7.07(1 \mathrm{H}, \mathrm{d}, J$ 8.3, Ar H), $6.78\left(1 \mathrm{H}, \mathrm{dd}, J 3.4,1.9\right.$, Ar H), $6.58\left(1 \mathrm{H}, \mathrm{dd}, J\right.$ 8.3, 2.5, Ar H); $\delta_{\mathrm{C}}\left(75 \mathrm{MHz}\right.$; DMSO- $\left.d_{6}\right) 159.2$ $(\mathrm{Cq}), 155.6(\mathrm{Cq}), 153.1(\mathrm{Cq}), 150.7(\mathrm{Cq}), 149.4(\mathrm{Cq}), 141.8(\mathrm{CH}), 136.0(\mathrm{Cq}), 133.6(\mathrm{Cq}), 130.8$ $(\mathrm{CH}), 126.9(\mathrm{CH}), 121.7(\mathrm{Cq}), 116.9(\mathrm{Cq}), 114.9(\mathrm{CH}), 112.6(\mathrm{CH}), 111.0(\mathrm{CH}), 100.8(\mathrm{CH}), 16.6$ $\left(\mathrm{CH}_{3}\right) ; m / z$ (MALDI-TOF) $352\left(\mathrm{MH}^{+}, 17 \%\right), 351\left(\mathrm{M}^{+}, 100\right)$; HRMS (ESI+) found for $\mathrm{MH}^{+}$ 352.08576, $\mathrm{C}_{17} \mathrm{H}_{14} \mathrm{~N}_{5} \mathrm{O}_{2} \mathrm{~S}^{+}$requires 352.08682 .

3-Morpholino-5-(1H-pyrrolo[2,3-b]pyridin-4-yl)-4H-1,2,6-thiadiazin-4-one (19). Similar treatment of 3-chloro-5-[(3-hydroxy-4-methylphenyl)amino]-4H-1,2,6-thiadiazin-4-one (11) (53.9 mg, $0.20 \mathrm{mmol}$ ) with (1H-pyrrolo[2,3-b]pyridin-4-yl)boronic acid $(30.2 \mathrm{mg}, 0.22 \mathrm{mmol})$ for $22 \mathrm{~h}$ gave after chromatography (DCM/ $t$-BuOMe, 50:50) the title compound 19 (36.7 mg, 58\%) as yellow needles, mp 256-257 ${ }^{\circ} \mathrm{C}$ (from EtOH/THF); $\mathrm{R}_{f} 0.75$ (DCM/t-BuOMe, 50:50); (found: $\mathrm{C}, 53.08 ; \mathrm{H}, 4.12 ; \mathrm{N}, 22.35 . \mathrm{C}_{14} \mathrm{H}_{13} \mathrm{~N}_{5} \mathrm{O}_{2} \mathrm{~S}$ requires $\mathrm{C}, 53.22 ; \mathrm{H}, 4.16 ; \mathrm{N}, 22.21 \%$ ); $\lambda_{\max }(\mathrm{THF}) / \mathrm{nm} 291$ (log $\varepsilon$ 3.63), 298 (3.62), 358 (3.71), $408 \mathrm{inf}(3.55) ; v_{\max } / \mathrm{cm}^{-1} 3140 \mathrm{w}$, 3069w, 2978w, 2887w, 2852w, 1603s, 1560w, 1493m, 1483m, 1439m, 1404m, 1327m, 1319m, $1310 \mathrm{~m}, 1283 \mathrm{~m}, 1269 \mathrm{~m}, 1248 \mathrm{~s}, 1217 \mathrm{~m}, 1192 \mathrm{~m}, 1124 \mathrm{~s}, 1065 \mathrm{~m}, 1007 \mathrm{~m}, 959 \mathrm{~m}, 922 \mathrm{~m}, 903 \mathrm{~m}$, 878m, 858m, 835m, 810s, 795s, 746m, 727m, 710m; $\delta_{\mathrm{H}}\left(300 \mathrm{MHz}\right.$; DMSO-d $\left.{ }_{6}\right) 11.76(1 \mathrm{H}$, br s, $\mathrm{NH}), 8.27(1 \mathrm{H}, \mathrm{d}, J$ 5.0, Ar H), $7.53(1 \mathrm{H}, \mathrm{dd}, J 3.2,2.7$, Ar H), $7.51(1 \mathrm{H}, \mathrm{d}, J 5.0$, Ar H), 6.60 $(1 \mathrm{H}, \mathrm{dd}, J 3.4,1.8, \mathrm{Ar} H), 3.78\left(4 \mathrm{H}\right.$, br. s, $\left.\mathrm{CH}_{2}\right), 3.72\left(4 \mathrm{H}\right.$, br. s, $\left.\mathrm{CH}_{2}\right) ; \delta_{\mathrm{C}}\left(75 \mathrm{MHz}\right.$; DMSO- $\left.d_{6}\right)$ $162.3(\mathrm{Cq}), 155.0(\mathrm{Cq}), 154.3(\mathrm{Cq}), 149.3(\mathrm{Cq}), 141.7(\mathrm{CH}), 134.0(\mathrm{Cq}), 126.8(\mathrm{CH}), 117.0(\mathrm{Cq})$, $114.9(\mathrm{CH}), 100.7(\mathrm{CH}), 65.7\left(\mathrm{CH}_{2}\right), 46.2\left(\mathrm{CH}_{2}\right) ; \mathrm{m} / z$ (MALDI-TOF) $316\left(\mathrm{M}+\mathrm{H}^{+}, 100 \%\right), 315$ $\left(\mathrm{M}^{+}, 89\right)$; HRMS (ESI+) found for $\mathrm{MH}^{+} 316.08558, \mathrm{C}_{14} \mathrm{H}_{14} \mathrm{~N}_{5} \mathrm{O}_{2} \mathrm{~S}^{+}$requires 316.08682.

3-(4-Methylpiperazin-1-yl)-5-(1H-pyrrolo[2,3-b]pyridin-4-yl)-4H-1,2,6-thiadiazin-4-one (20). Similar treatment of 3-chloro-5-(4-methylpiperazin-1-yl)-4H-1,2,6-thiadiazin-4-one (12) (49.4 mg, $0.20 \mathrm{mmol})$ with (1H-pyrrolo[2,3-b]pyridin-4-yl)boronic acid $(26.0 \mathrm{mg}, 0.22 \mathrm{mmol})$ for $1 \mathrm{~h}$ gave after chromatography (DCM/THF, 50:50) the title compound $20(60.8 \mathrm{mg}, 93 \%)$ as yellow needles, $\mathrm{mp} 195-196{ }^{\circ} \mathrm{C}$ (from $c$-hexane $/ \mathrm{CHCl}_{3}$ ); $\mathrm{R}_{f} 0.21$ (DCM/THF, 50:50); (found: C, 54.59; $\mathrm{H}, 5.14 ; \mathrm{N}, 25.36 . \mathrm{C}_{15} \mathrm{H}_{16} \mathrm{~N}_{6}$ OS requires $\left.\mathrm{C}, 54.86 ; \mathrm{H}, 4.91 ; \mathrm{N}, 25.59 \%\right) ; \lambda_{\max }(\mathrm{DCM}) / \mathrm{nm}$ 259 (log $\varepsilon 4.08), 358$ (4.26), 409 (4.06); $v_{\max } / \mathrm{cm}^{-1} 3134 \mathrm{w}, 2938 \mathrm{w}, 2884 \mathrm{w}, 2843 \mathrm{w}, 2787 \mathrm{w}, 1611 \mathrm{~m}$, $1593 \mathrm{~m}, 1564 \mathrm{~m}, 1463 \mathrm{~m}, 1447 \mathrm{~m}, 1410 \mathrm{~m}, 1368 \mathrm{w}, 1331 \mathrm{~m}, 1281 \mathrm{~m}, 1259 \mathrm{~m}, 1234 \mathrm{~m}, 1219 \mathrm{~m}, 1196 \mathrm{~m}$, $1165 \mathrm{~m}, 1148 \mathrm{~m}, 1090 \mathrm{~m}, 1078 \mathrm{~m}, 1001 \mathrm{~m}, 1051 \mathrm{~m}, 895 \mathrm{~m}, 870 \mathrm{~m}, 827 \mathrm{~s}, 789 \mathrm{~s}, 746 \mathrm{~m}, 733 \mathrm{~m}, 708 \mathrm{~s}$, 660m, 613m; $\delta_{\mathrm{H}}\left(500 \mathrm{MHz} ; \mathrm{DMSO}-d_{6}\right) 11.76(1 \mathrm{H}, \mathrm{s}, \mathrm{NH}), 8.27(1 \mathrm{H}, \mathrm{d}, J$ 5.0, Ar H), $7.53(1 \mathrm{H}$, dd, J 3.0, 3.0, Ar H), $7.51(1 \mathrm{H}, \mathrm{d}, J$ 5.0, Ar H), $6.60(1 \mathrm{H}, \mathrm{dd}, J 3.4,1.9$, Ar H), 3.77 (4H, br. s, 
$\left.\mathrm{CH}_{2}\right), 2.45\left(4 \mathrm{H}, \mathrm{t}, J\right.$ J.0, $\left.\mathrm{CH}_{2}\right), 2.22\left(3 \mathrm{H}, \mathrm{s}, \mathrm{CH}_{3}\right) ; \delta_{\mathrm{C}}\left(125 \mathrm{MHz} ; \mathrm{DMSO}-d_{6}\right) 162.3(\mathrm{Cq}), 155.0$ $(\mathrm{Cq}), 154.2(\mathrm{Cq}), 149.3(\mathrm{Cq}), 141.8(\mathrm{CH}), 134.1(\mathrm{Cq}), 126.8(\mathrm{CH}), 117.0(\mathrm{Cq}), 114.9(\mathrm{CH}), 100.7$ $(\mathrm{CH}), 54.2\left(\mathrm{CH}_{2}\right), 45.54\left(\mathrm{CH}_{2}\right), 45.5\left(\mathrm{CH}_{3}\right) ; \mathrm{m} / z(\mathrm{APCI}+) 329\left(\mathrm{MH}^{+}, 100 \%\right), 309$ (34); HRMS (ESI+) found for $\mathrm{MH}^{+} 329.11702, \mathrm{C}_{15} \mathrm{H}_{17} \mathrm{~N}_{6} \mathrm{OS}^{+}$requires 329.11845.

5-(3-Hydroxyphenyl)-3-[(1H-indazol-5-yl)amino]-4H-1,2,6-thiadiazin-4-one (23) (General procedure B). To a mixture of 5-chloro-3-[(1H-indazol-5-yl)amino]-4H-1,2,6-thiadiazin-4-one (13) (55.9 mg, $0.20 \mathrm{mmol}$ ), (3-hydroxyphenyl)boronic acid ( $55.2 \mathrm{mg}, 0.40 \mathrm{mmol}), \mathrm{Pd}(\mathrm{dppf}) \mathrm{Cl}_{2}$ $(14.6 \mathrm{mg}, 10 \mathrm{~mol} \%)$ and powdered dry $\mathrm{Na}_{2} \mathrm{CO}_{3}(42.4 \mathrm{mg}, 0.40 \mathrm{mmol})$, in a sealed tube, was added dioxane $(0.9 \mathrm{~mL})$ and $\mathrm{H}_{2} \mathrm{O}(0.1 \mathrm{~mL})$. The stirred suspension was then deaerated by bubbling of Ar through it for 5 min and then heated at ca. $140{ }^{\circ} \mathrm{C}$ under Ar until complete consumption of the starting thiadiazine (TLC, $1.5 \mathrm{~h}$ ). The mixture was cooled to ca. $20^{\circ} \mathrm{C}$, adsorbed onto silica and chromatographed (DCM/t-BuOMe, 50:50) to give the title compound $23\left(46.1 \mathrm{mg}, 68 \%\right.$ ) as orange needles, $\mathrm{mp} 282-283{ }^{\circ} \mathrm{C}$ (from $\mathrm{MeOH} / \mathrm{THF}$ ); $\mathrm{R}_{f}$ 0.52 (DCM/t-BuOMe, 50:50); (found: $\mathrm{C}, 59.79 ; \mathrm{H}, 3.43 ; \mathrm{N}, 20.81 . \mathrm{C}_{16} \mathrm{H}_{11} \mathrm{~N}_{5} \mathrm{O}_{2} \mathrm{~S}$ requires C, 56.97; H, 3.29; N, 20.76\%); $\lambda_{\max }(\mathrm{THF}) / \mathrm{nm} 326 \inf (\log \varepsilon 3.81), 374$ (4.00), $391 \inf (3.79)$, 447 (3.49); $v_{\max } / \mathrm{cm}^{-1} 3331 \mathrm{w}, 1605 \mathrm{~m}, 1591 \mathrm{~m}, 1584 \mathrm{~m}, 1580 \mathrm{~m}, 1553 \mathrm{~s}, 1510 \mathrm{~m}, 1503 \mathrm{~m}, 1346 \mathrm{~m}$, $1300 \mathrm{~m}, 1229 \mathrm{~m}, 1169 \mathrm{w}, 1086 \mathrm{w}, 997 \mathrm{w}, 968 \mathrm{w}, 951 \mathrm{~m}, 895 \mathrm{w}, 866 \mathrm{~m}, 829 \mathrm{~m}, 814 \mathrm{~m}, 800 \mathrm{~m}, 814 \mathrm{~m}$, $779 \mathrm{~m}, 754 \mathrm{~m} ; \delta_{\mathrm{H}}\left(500 \mathrm{MHz} ; \mathrm{DMSO}-d_{6}\right) 13.06(1 \mathrm{H}, \mathrm{s}), 10.15(1 \mathrm{H}, \mathrm{s}), 9.60(1 \mathrm{H}, \mathrm{s}), 8.25(1 \mathrm{H}$, s, Ar H), $8.08(1 \mathrm{H}, \mathrm{s}, \operatorname{Ar} H), 7.68(1 \mathrm{H}, \mathrm{dd}, J$ 8.9, 1.4, Ar H), 7.56-7.51 (3H, m, Ar H), 7.27 $(1 \mathrm{H}, \mathrm{dd}, J$ J 7.8, 7.8, $\mathrm{Ar} H), 6.86(1 \mathrm{H}, \mathrm{dd}, J$ 8.3, 2.4, $\mathrm{Ar} H) ; \delta_{\mathrm{C}}(125 \mathrm{MHz} \text {; DMSO-d })^{1} 159.6(\mathrm{Cq})$, $156.4(\mathrm{Cq}), 152.5(\mathrm{Cq}), 151.0(\mathrm{Cq}), 137.2(\mathrm{Cq}), 136.5(\mathrm{Cq}), 133.5(\mathrm{CH}), 130.9(\mathrm{Cq}), 128.9(\mathrm{CH})$, $122.6(\mathrm{Cq}), 122.1(\mathrm{CH}), 119.0(\mathrm{CH}), 116.6(\mathrm{CH}), 114.9(\mathrm{CH}), 111.5(\mathrm{CH}), 110.1(\mathrm{CH}) ; \mathrm{m} / \mathrm{z}$ (APCI+) $338\left(\mathrm{MH}^{+}, 100 \%\right), 313(36)$; HRMS (ESI+) found for $\mathrm{MH}^{+} 338.06985, \mathrm{C}_{16} \mathrm{H}_{12} \mathrm{~N}_{5} \mathrm{O}_{2} \mathrm{~S}^{+}$ requires 338.07117.

5-(5-Hydroxy-2-methylphenyl)-3-[(1H-indazol-5-yl)amino]-4H-1,2,6-thiadiazin-4-one (24). Similar treatment of 5-chloro-3-[(1H-indazol-5-yl)amino]-4H-1,2,6-thiadiazin-4-one (13) $(55.9 \mathrm{mg}$, $0.20 \mathrm{mmol}$ ) with (5-hydroxy-2-methylphenyl)boronic acid $(60.8 \mathrm{mg}, 0.40 \mathrm{mmol})$ for $1.5 \mathrm{~h}$ gave after chromatography (DCM/t-BuOMe, 75:25) the title compound $24(48.8 \mathrm{mg}, 69 \%)$ as yellow needles, mp $268-269{ }^{\circ} \mathrm{C}$ (from $\mathrm{PhH} / \mathrm{THF}$ ); $\mathrm{R}_{f} 0.35$ (DCM/t-BuOMe, 75:25); (found: $\mathrm{C}, 58.46 ; \mathrm{H}, 3.51 ; \mathrm{N}, 19.69 . \mathrm{C}_{17} \mathrm{H}_{13} \mathrm{~N}_{5} \mathrm{O}_{2} \mathrm{~S}$ requires $\mathrm{C}, 58.11 ; \mathrm{H}, 3.73 ; \mathrm{N}, 19.93 \%$ ); $\lambda_{\max }(\mathrm{THF}) / \mathrm{nm} 307$ (log $\left.\varepsilon 3.90\right), 358$ (3.93), 426 (3.44); $v_{\max } / \mathrm{cm}^{-1} 3337 \mathrm{w}, 3233 \mathrm{w}, 2689 \mathrm{w}$, $1612 \mathrm{~m}, 1591 \mathrm{~m}, 1576 \mathrm{~m}, 1557 \mathrm{~s}, 1514 \mathrm{~m}, 1504 \mathrm{~m}, 1333 \mathrm{~m}, 1300 \mathrm{~m}, 1267 \mathrm{w}, 1238 \mathrm{w}, 1213 \mathrm{w}, 1167 \mathrm{w}$, $1097 \mathrm{w}, 966 \mathrm{w}, 953 \mathrm{~m}, 937 \mathrm{w}, 883 \mathrm{w}, 866 \mathrm{~m}, 847 \mathrm{~m}, 802 \mathrm{~m}, 752 \mathrm{~m} ; \delta_{\mathrm{H}}\left(500 \mathrm{MHz}\right.$; DMSO-d $\left.{ }_{6}\right) 13.06$ $(1 \mathrm{H}, \mathrm{s}), 10.11(1 \mathrm{H}, \mathrm{s}), 9.35(1 \mathrm{H}, \mathrm{s}), 8.26(1 \mathrm{H}, \mathrm{d}, J$ 1.2, $\operatorname{Ar} H), 8.08(1 \mathrm{H}, \mathrm{s}, \mathrm{Ar} H), 7.69(1 \mathrm{H}, \mathrm{dd}$, J 9.0, 1.9, Ar H), $7.53(1 \mathrm{H}, \mathrm{d}, J$ 8.9, $\operatorname{Ar} H), 7.07(1 \mathrm{H}, \mathrm{d}, J$ J.3, $\operatorname{Ar} H), 6.78(1 \mathrm{H}, \mathrm{d}, J$ 2.6, $\operatorname{Ar} H)$, $6.75(1 \mathrm{H}, \mathrm{dd}, J$ 8.2, 2.6, $\mathrm{Ar} H), 2.10\left(3 \mathrm{H}, \mathrm{s}, \mathrm{CH}_{3}\right) ; \delta_{\mathrm{C}}(125 \mathrm{MHz}$; DMSO-d $) 159.0(\mathrm{Cq}), 155.8$ $(\mathrm{Cq}), 154.7(\mathrm{Cq}), 152.1(\mathrm{Cq}), 137.2(\mathrm{Cq}), 136.3(\mathrm{Cq}), 133.5(\mathrm{CH}), 130.9(\mathrm{CH}), 130.8(\mathrm{Cq}), 126.1$ (Cq), $122.6(\mathrm{Cq}), 122.1(\mathrm{CH}), 115.9(\mathrm{CH}), 113.8(\mathrm{CH}), 111.5(\mathrm{CH}), 110,1(\mathrm{CH}), 18.6\left(\mathrm{CH}_{3}\right)$; $m / z(\mathrm{APCI}+) 352\left(\mathrm{MH}^{+}, 100 \%\right), 177\left(\mathrm{M}^{+}, 67\right)$; HRMS (ESI+) found for $\mathrm{MH}^{+} 352.08560$, $\mathrm{C}_{17} \mathrm{H}_{14} \mathrm{~N}_{5} \mathrm{O}_{2} \mathrm{~S}^{+}$requires 352.08682 .

3-[(1H-Indazol-5-yl)amino]-5-(3-methoxyphenyl)-4H-1,2,6-thiadiazin-4-one (25). Similar treatment of 5-chloro-3-[(1H-indazol-5-yl)amino]-4H-1,2,6-thiadiazin-4-one (13) $(55.9 \mathrm{mg}, 0.20 \mathrm{mmol})$ with (3-methoxyphenyl)boronic acid $(60.8 \mathrm{mg}, 0.40 \mathrm{mmol})$ for $2 \mathrm{~h}$ gave after chromatography (DCM/t-BuOMe, 95:5) the title compound $25(55.1 \mathrm{mg}, 78 \%)$ as orange needles, $\mathrm{mp}$ 220-221 ${ }^{\circ} \mathrm{C}$ (from EtOH/THF); $\mathrm{R}_{f} 0.29$ (DCM/t-BuOMe, 95:5); (found: C, 58.20; H, 3.65; N, 19.89. $\mathrm{C}_{17} \mathrm{H}_{13} \mathrm{~N}_{5} \mathrm{O}_{2} \mathrm{~S}$ requires $\left.\mathrm{C}, 58.11 ; \mathrm{H}, 3.73 ; \mathrm{N}, 19.93 \%\right) ; \lambda_{\max }(\mathrm{DCM}) / \mathrm{nm} 376(\log \varepsilon 4.04)$, 453 (3.53); $v_{\max } / \mathrm{cm}^{-1} 3335 \mathrm{w}(\mathrm{N}-\mathrm{H}), 2943 \mathrm{w}(\mathrm{C}-\mathrm{H}), 1605 \mathrm{~m}, 1595 \mathrm{~m}, 1587 \mathrm{~m}, 1547 \mathrm{~m}, 1512 \mathrm{~m}$, $1501 \mathrm{~m}, 1491 \mathrm{~m}, 1343 \mathrm{~m}, 1323 \mathrm{w}, 1287 \mathrm{~m}, 1244 \mathrm{~m}, 1227 \mathrm{~m}, 1215 \mathrm{~m}, 1182 \mathrm{w}, 1167 \mathrm{w}, 1038 \mathrm{~m}, 941 \mathrm{~m}$, $868 \mathrm{~m}, 829 \mathrm{~m}, 782 \mathrm{~m}, 731 \mathrm{~m} ; \delta_{\mathrm{H}}\left(300 \mathrm{MHz}\right.$; DMSO- $\left.d_{6}\right) 13.06(1 \mathrm{H}$, br. s, NH) $10.22(1 \mathrm{H}, \mathrm{s}$, $\mathrm{NH}), 8.26(1 \mathrm{H}, \mathrm{d}, J 1.4, \operatorname{Ar} H), 8.08(1 \mathrm{H}, \mathrm{s}, \operatorname{Ar} H), 7.72-7.66(3 \mathrm{H}, \mathrm{m}, \operatorname{Ar} H), 7.54(1 \mathrm{H}, \mathrm{d}$, J 9.1, Ar H), $7.41(1 \mathrm{H}, \mathrm{dd}, J$ 8.0, 8.0, Ar H), $7.05(1 \mathrm{H}, \mathrm{ddd}, J$ 4.8, 2.5, 0.9, Ar H), $3.81(3 \mathrm{H}$, $\left.\mathrm{s}, \mathrm{CH}_{3}\right) ; \delta_{\mathrm{C}}\left(75 \mathrm{MHz} ; \mathrm{DMSO}-d_{6}\right) 159.6(\mathrm{Cq}), 158.7(\mathrm{Cq}), 152.5(\mathrm{Cq}), 150.6(\mathrm{Cq}), 137.2(\mathrm{Cq})$, $136.5(\mathrm{Cq}), 133.5(\mathrm{CH}), 130.9(\mathrm{Cq}), 129.1(\mathrm{CH}), 122.6(\mathrm{Cq}), 122.0(\mathrm{CH}), 120.4(\mathrm{CH}), 115.2(\mathrm{CH})$, 
$113.4(\mathrm{CH}), 111.5(\mathrm{CH}), 110.1(\mathrm{CH}), 55.1\left(\mathrm{CH}_{3}\right) ; \mathrm{m} / z$ (APCI+) $352\left(\mathrm{MH}^{+}, 67 \%\right), 231(52), 177$ (46), 152 (98), 135 (82), 109 (100); HRMS (ESI+) found for $\mathrm{MH}^{+} 352.08557, \mathrm{C}_{17} \mathrm{H}_{14} \mathrm{~N}_{5} \mathrm{O}_{2} \mathrm{~S}^{+}$ requires 352.08682 .

(2-Fluoropyridin-4-yl)-3-[(1H-indazol-5-yl)amino]-4H-1,2,6-thiadiazin-4-one (26). Similar treatment of 5-chloro-3-[(1H-indazol-5-yl)amino]-4H-1,2,6-thiadiazin-4-one (13) (55.9 mg, $0.20 \mathrm{mmol})$ with (2-fluoropyridin-4-yl)boronic acid $(56.4 \mathrm{mg}, 0.40 \mathrm{mmol})$ for $1 \mathrm{~h}$ gave after chromatography (DCM/t-BuOMe, 50:50) the title compound $26(54.3 \mathrm{mg}, 92 \%)$ as orange needles, $\mathrm{mp} 280{ }^{\circ} \mathrm{C}$ (decomp., from EtOH/ $\mathrm{CHCl}_{3}$ ); $\mathrm{R}_{f} 0.79$ (DCM/t-BuOMe, 50:50); (found: C, 52.80; H, 2.72; N, 24.42. $\mathrm{C}_{15} \mathrm{H}_{9} \mathrm{FN}_{6} \mathrm{OS}$ requires $\left.\mathrm{C}, 52.94 ; \mathrm{H}, 2.67 ; \mathrm{N}, 24.69 \%\right) ; \lambda_{\max }(\mathrm{DCM}) / \mathrm{nm} 252(\log \varepsilon 4.02)$, 322 (3.80), 384 (3.99), $453 \mathrm{inf}(3.68) ; v_{\max } / \mathrm{cm}^{-1} 3319 \mathrm{w}$ and $3221 \mathrm{br}(\mathrm{N}-\mathrm{H}), 1620 \mathrm{~m}, 1612 \mathrm{~m}$, $1587 \mathrm{~m}, 1560 \mathrm{~m}, 1557 \mathrm{~s}, 1551 \mathrm{~s}, 1547 \mathrm{~s}, 1503 \mathrm{~s}, 1483 \mathrm{~m}, 1381 \mathrm{~m}, 1352 \mathrm{w}, 1288 \mathrm{~m}, 1223 \mathrm{~m}, 1202 \mathrm{w}$, $1161 \mathrm{~m}, 1007 \mathrm{~m}, 937 \mathrm{~m}, 837 \mathrm{~s}, 799 \mathrm{~s} ; \delta_{\mathrm{H}}(500 \mathrm{MHz}$; DMSO-d $) 13.10(1 \mathrm{H}, \mathrm{s}, \mathrm{NH}), 10.41(1 \mathrm{H}, \mathrm{s}$, $\mathrm{NH}), 8.38(1 \mathrm{H}, \mathrm{d}, J$ 5.3, Ar H), $7.24(1 \mathrm{H}, \mathrm{d}, J$ 1.2, Ar H), $8.09(1 \mathrm{H}, \mathrm{s}, \operatorname{Ar} H), 8.01(1 \mathrm{H}, \mathrm{d}, J$ 5.2, Ar H), $7.83(1 \mathrm{H}, \mathrm{s}, \operatorname{Ar} H), 7.70(1 \mathrm{H}, \mathrm{dd}, J 8.9,1.8, \operatorname{Ar} H), 7.55(1 \mathrm{H}, \mathrm{d}, J 8.9, \operatorname{Ar~H}) ; \delta_{\mathrm{C}}(125 \mathrm{MHz}$; DMSO- $\left.d_{6}\right) 163.3\left(\mathrm{Cq}, \mathrm{d},{ }^{1} J_{\mathrm{CF}} 232.5\right), 159.7(\mathrm{Cq}), 153.1(\mathrm{Cq}), 147.8\left(\mathrm{CH}, \mathrm{d},{ }^{3} J_{\mathrm{CF}} 15.3\right), 147.5(\mathrm{Cq}$, $\left.\mathrm{d},{ }^{3} J_{\mathrm{CF}} 8.7\right), 146.3\left(\mathrm{Cq}, \mathrm{d},{ }^{4} J_{\mathrm{CF}} 3.7\right), 137.3(\mathrm{Cq}), 133.6(\mathrm{CH}), 130.5(\mathrm{Cq}), 122.6(\mathrm{Cq}), 122.2(\mathrm{CH})$, $120.0\left(\mathrm{CH}, \mathrm{d},{ }^{4} J_{\mathrm{CF}} 3.7\right), 112.2(\mathrm{CH}), 110.2(\mathrm{CH}), 107.3\left(\mathrm{CH}, \mathrm{d},{ }^{2} J_{\mathrm{CF}} 40.3\right) ; \mathrm{m} / \mathrm{z}$ (APCI+) 341 $\left(\mathrm{MH}^{+}, 100 \%\right)$; HRMS (ESI+) found for $\mathrm{MH}^{+} 341.06105, \mathrm{C}_{15} \mathrm{H}_{10} \mathrm{FN}_{6} \mathrm{OS}^{+}$requires 341.06208 .

\subsubsection{Preparation of 3,5-Diaminosubstituted Thiadiazines}

5-(4-Methylpiperazin-1-yl)-3-[(1H-pyrrolo[2,3-b]pyridin-4-yl)amino]-4H-1,2,6-thiadiazin-4-one (21) (general procedure). To a mixture of 3-chloro-5-(4-methylpiperazin-1-yl)-4H-1,2,6-thiadiazin4-one (12) (49.4 mg, $0.20 \mathrm{mmol}), \mathrm{Pd}\left[3,5-\left(\mathrm{F}_{3} \mathrm{C}\right)_{2} \mathrm{C}_{6} \mathrm{H}_{3}\right]_{3}(5.3 \mathrm{mg}, 1.25 \mathrm{~mol} \%)$, DPEPhos (5.3 mg, $5 \mathrm{~mol} \%)$, powdered dry $\mathrm{K}_{2} \mathrm{CO}_{3}(66.4 \mathrm{mg}, 0.48 \mathrm{mmol})$ and $1 \mathrm{H}$-pyrrolo[2,3- $b$ ]pyridin-4-amine $(29.3 \mathrm{mg}, 0.22 \mathrm{mmol})$ was added dry dioxane $(4 \mathrm{~mL})$. The stirred suspension was then deaerated by bubbling of Ar through it for $5 \mathrm{~min}$ and then heated at reflux under Ar until complete consumption of the starting thiadiazine (TLC, $2 \mathrm{~h}$ ). The mixture was cooled to ca. $20{ }^{\circ} \mathrm{C}$, then filtered and washed with $\mathrm{H}_{2} \mathrm{O}(5 \mathrm{~mL})$ and $\mathrm{EtOH}(5 \mathrm{~mL})$, and dried under vacuum to give the title compound $21\left(43.6 \mathrm{mg}, 64 \%\right.$ ) as yellow plates, $\mathrm{mp} 286-287{ }^{\circ} \mathrm{C}$ (from c-hexane $/ \mathrm{CHCl}_{3}$ ); $\mathrm{R}_{f} 0.30$ (THF); (found: $\mathrm{C}, 52.41 ; \mathrm{H}, 4.83 ; \mathrm{N}, 28.47 . \mathrm{C}_{15} \mathrm{H}_{17} \mathrm{~N}_{7} \mathrm{OS}$ requires C, 52.46; H, 4.99; N, 28.55\%); $\lambda_{\max }(\mathrm{DCM}) / \mathrm{nm} 272$ (log ع 4.06), 338 (4.71), 351 (4.71), 442 (4.17); $v_{\max } / \mathrm{cm}^{-1} 3130 \mathrm{w}, 3022 \mathrm{w}, 2961 \mathrm{w}, 1841 \mathrm{w}, 2792 \mathrm{w}, 1611 \mathrm{~m}, 1587 \mathrm{~s}, 1549 \mathrm{~m}, 1535 \mathrm{~m}, 1503 \mathrm{~m}$, $1485 \mathrm{~m}, 1479 \mathrm{~m}, 1443 \mathrm{~m}, 1439 \mathrm{~m}, 1402 \mathrm{~m}, 1333 \mathrm{~m}, 1306 \mathrm{~m}, 1290 \mathrm{~m}, 1271 \mathrm{~m}, 1252 \mathrm{w}, 1225 \mathrm{~m}, 1207 \mathrm{w}$, $1161 \mathrm{~m}, 1121 \mathrm{~m}, 951 \mathrm{w}, 899 \mathrm{~m}, 858 \mathrm{w}, 818 \mathrm{~m}, 787 \mathrm{~m}, 781 \mathrm{~m}, 773 \mathrm{~m}, 743 \mathrm{~m}, 704 \mathrm{~m} ; \delta_{\mathrm{H}}(500 \mathrm{MHz}$; DMSO-d 6$) 11.66(1 \mathrm{H}, \mathrm{s}, \mathrm{NH}), 9.28(1 \mathrm{H}, \mathrm{s}, \mathrm{NH}), 8.13(1 \mathrm{H}, \mathrm{d}, J 5.4, \mathrm{Ar} H), 7.73(1 \mathrm{H}, \mathrm{d}, J$ 5.4, Ar H), $7.38\left(1 \mathrm{H}, \mathrm{dd}, J\right.$ 2.9, 2.9, Ar H), $6.61(1 \mathrm{H}, \mathrm{dd}, J 3.3,1.8, \mathrm{Ar} H), 3.64\left(4 \mathrm{H}\right.$, br. s, $\left.\mathrm{CH}_{2}\right), 2.25$ $\left(3 \mathrm{H}, \mathrm{s}, \mathrm{CH}_{3}\right), 4 \mathrm{H}$ missing due to overlap with $\mathrm{H}_{2} \mathrm{O}$ peak $\left(2 \times \mathrm{CH}_{2}\right) ; \delta_{\mathrm{C}}\left(125 \mathrm{MHz}\right.$; DMSO- $\left.d_{6}\right)$ $156.7(\mathrm{Cq}), 151.6(\mathrm{Cq}), 149.4(\mathrm{Cq}), 148.6(\mathrm{Cq}), 143.6(\mathrm{CH}), 137.7(\mathrm{Cq}), 124.2(\mathrm{CH}), 110.2(\mathrm{Cq})$, $103.4(\mathrm{CH}), 97.0(\mathrm{CH}), 54.0\left(\mathrm{CH}_{2}\right), 45.9\left(\mathrm{CH}_{2}\right), 45.4\left(\mathrm{CH}_{3}\right) ; m / z(\mathrm{MALDI}-\mathrm{TOF}) 344\left(\mathrm{MH}^{+}\right.$, $100 \%), 287$ (95); HRMS found for $\mathrm{MH}^{+} 344.12803, \mathrm{C}_{15} \mathrm{H}_{18} \mathrm{~N}_{7} \mathrm{OS}^{+}$requires 344.12935.

3-[(1H-Indazol-5-yl)amino]-5-(4-methylpiperazin-1-yl)-4H-1,2,6-thiadiazin-4-one (22). Similar treatment of 3-chloro-5-(4-methylpiperazin-1-yl)-4H-1,2,6-thiadiazin-4-one (12) (49.4 mg, $0.20 \mathrm{mmol})$, with $1 \mathrm{H}$-indazol-5-amine $(29.3 \mathrm{mg}, 0.22 \mathrm{mmol})$ after $16 \mathrm{~h}$ gave after chromatography (DCM/t-BuOMe/ $\left.\mathrm{Et}_{3} \mathrm{~N}, 50: 49: 1\right)$ the title compound $22(65.2 \mathrm{mg}, 92 \%)$ as yellow needles, $\mathrm{mp} 262-263{ }^{\circ} \mathrm{C}$ (from EtOH/THF); $\mathrm{R}_{f} 0.16$ (DCM/t-BuOMe/Et $3 \mathrm{~N}, 50: 49: 1$ ); (found: $\mathrm{C}, 52.70 ; \mathrm{H}, 4.78 ; \mathrm{N}, 28.62 . \mathrm{C}_{15} \mathrm{H}_{17} \mathrm{~N}_{7} \mathrm{OS}$ requires $\mathrm{C}, 52.46 ; \mathrm{H}, 4.99 ; \mathrm{N}, 28.55 \%$ ); $\lambda_{\max }(\mathrm{THF}) / \mathrm{nm} 263$ (log $\left.\varepsilon 4.30\right), 308$ (3.69), 469 (3.00); $v_{\max } / \mathrm{cm}^{-1} 3339 \mathrm{w}, 1601 \mathrm{~m}, 1585 \mathrm{~m}$, $1557 \mathrm{~m}, 1503 \mathrm{~m}, 1493 \mathrm{~m}, 1437 \mathrm{w}, 1404 \mathrm{w}, 1306 \mathrm{w}, 1287 \mathrm{w}, 1277 \mathrm{w}, 1246 \mathrm{w}, 1221 \mathrm{~m}, 1128 \mathrm{~m}, 1078 \mathrm{~m}$, 1053s, 978m, 945m, 870m, 799s, 733m; $\delta_{\mathrm{H}}(500 \mathrm{MHz}$; DMSO-d $) 13.01(1 \mathrm{H}$, br. s, NH), 9.65 $(1 \mathrm{H}, \mathrm{s}, \mathrm{NH}), 8.21(1 \mathrm{H}, \mathrm{s}, \mathrm{Ar} H), 8.03(1 \mathrm{H}, \mathrm{s}, \operatorname{Ar} H), 7.61(1 \mathrm{H}, \mathrm{dd}, J 9.0,1.8, \operatorname{Ar} H), 7.49(1 \mathrm{H}, \mathrm{d}$, J 9.0, $\mathrm{Ar} \mathrm{H}), 3.66\left(4 \mathrm{H}, \mathrm{m}, \mathrm{CH}_{2}\right), 2.86\left(4 \mathrm{H}, \mathrm{m}, \mathrm{CH}_{2}\right), 3 \mathrm{H}$ missing due to overlap with DMSO peak $\left(1 \times \mathrm{CH}_{3}\right) ; \delta_{\mathrm{C}}(125 \mathrm{MHz}$; DMSO-d 6$) 156.8(\mathrm{Cq}), 151.0(\mathrm{Cq}), 149.9(\mathrm{Cq}), 136.9(\mathrm{Cq}), 133.2$ $(\mathrm{CH}), 131.8(\mathrm{Cq}), 122.6(\mathrm{Cq}), 121.7(\mathrm{CH}), 110.2(\mathrm{CH}), 109.9(\mathrm{CH}), 53.1\left(\mathrm{CH}_{2}\right), 45.0\left(\mathrm{CH}_{2}\right), 44.1$ 
$\left(\mathrm{CH}_{3}\right) ; m / z$ (MALDI-TOF) $344\left(\mathrm{MH}^{+}, 100 \%\right), 287$ (68); HRMS found for $\mathrm{MH}^{+} 344.12806$, $\mathrm{C}_{15} \mathrm{H}_{18} \mathrm{~N}_{7} \mathrm{OS}^{+}$requires 344.12935 .

Supplementary Materials: The following are available online, mol file, HRMS spectra on the final compounds, ${ }^{1} \mathrm{H}$ and ${ }^{13} \mathrm{C}$ NMR spectra on all new compounds.

Author Contributions: A.S.K., M.P.E., D.H.D., P.A.K., C.R.M.A. conceived and designed the study; A.S.K., M.P.E., T.L., C.D.T., K.A.M., C.R.M.A. performed the experiments; A.S.K., M.P.E., T.L., C.D.T., K.A.M., G.L.J., P.A.K., D.J.C., C.R.M.A. analyzed the data; A.S.K., P.A.K., C.R.M.A. edited the paper; C.R.M.A. wrote the paper and all authors approved the final manuscript. All authors have read and agreed to the published version of the manuscript.

Funding: This research was funded by the Cyprus Research Promotion Foundation, Grant No. NEAYPODOMH/NEKYP/0308/02. This work was partly supported by the NIH Common Fund Illuminating the Druggable Genome (IDG) program (NIH Grant U24DK116204).

Institutional Review Board Statement: Not applicable.

Informed Consent Statement: Not applicable.

Data Availability Statement: Not applicable.

Acknowledgments: The authors thank the following organizations and companies in Cyprus for generous donations of chemicals and glassware: The State General Laboratory; the Agricultural Research Institute; the Ministry of Agriculture; MedoChemie, Ltd.; Medisell, Ltd.; and Biotronics, Ltd. Furthermore, we thank the A. G. Leventis Foundation for helping to establish the NMR facility at the University of Cyprus. We also thank the Biocenter Finland/DDCB for financial support towards the goals of our work and the CSC-IT Center for Science Ltd. (Finland) for the allocation of computational resources. In addition, we are grateful for LC-MS/HRMS support provided by Brandie Ehrmann and Diane E. Wallace in the Mass Spectrometry Core Laboratory at the University of North Carolina at Chapel Hill. The core is supported by the National Science Foundation under grant no. CHE-1726291. We also acknowledge-The SGC is a registered charity (number 1097737) that receives funds from AbbVie, Bayer Pharma AG, Boehringer Ingelheim, Canada Foundation for Innovation, Eshelman Institute for Innovation, Genome Canada, Innovative Medicines Initiative (EU/EFPIA), Janssen, Merck \& Co., Novartis Pharma AG, Ontario Ministry of Economic Development and Innovation, Pfizer, São Paulo Research Foundation-FAPESP, Takeda, and Wellcome Trust.

Conflicts of Interest: The authors declare no conflict of interest.

Sample Availability: Samples of the compounds are available from the authors.

\section{References}

1. Boström:, J.; Brown, D.G.; Young, R.J; Keserü, G.M. Expanding the medicinal chemistry synthetic toolbox. Nat. Rev. Drug Discov. 2018, 17, 709-727. [CrossRef]

2. Virshup, A.M.; Contreras-García, J.; Wipf, P.; Yang, W.; Beratan, D.N. Stochastic Voyages into Uncharted Chemical Space Produce a Representative Library of All Possible Drug-Like Compounds. J. Am. Chem. Soc. 2013, 135, 7296-7303. [CrossRef] [PubMed]

3. Wang, J.; Hou, T. Drug and drug candidate building block analysis. J. Chem. Inf. Model. 2010, 50, 55-67. [CrossRef]

4. Taylor, R.D.; MacCoss, M.; Lawson, A.D.G. Rings in drugs. J. Med. Chem. 2014, 57, 5845-5859. [CrossRef] [PubMed]

5. Lücking, U. Neglected sulfur(vi) pharmacophores in drug discovery: Exploration of novel chemical space by the interplay of drug design and method development. Org. Chem. Front. 2019, 6, 1319-1324. [CrossRef]

6. Schiesser, S.; Cox, R.J.; Czechtizky, W. The powerful symbiosis between synthetic and medicinal chemistry. Future Med. Chem. 2021, 13, 941-944. [CrossRef]

7. Peake, C.J.; Harnish, W.N.; Davidson, B.L. Mono-5-substituted-3-chloro-4H-1,2,6-thiadiazin-4-one antifungal agents. U.S. Patent 4,097,594, 27 June 1978.

8. Peake, C.J.; Harnish, W.N.; Davidson, B.L. Mono-5-substituted-thio-3-chloro-4H-1,2,6-thiadiazin-4-one antifungal agents. U.S. Patent 4,100,281, 1 April 1978.

9. Peake, C.J.; Harnish, W.N.; Davidson, B.L. 3-Chloro-5-(optionally substituted heterocycloxy)-4H-1,2,6-thiadiazin-4-one antifungal agents. U.S. Patent 4,143,138, 6 March 1979.

10. Peake, C.J.; Harnish, W.N.; Davidson, B.L. Mono-5-substituted-3-chloro-4H-1,2,6-thiadiazin-4-one antifungal agents. U.S. Patent 4,201,780, 6 May 1980.

11. Portnoy, R.C. Thiadiazinone plant disease control agents. U.S. Patent 4,497,807, 5 February 1985. 
12. Chochos, C.L.; Kalogirou, A.S.; Ye, T.; Tatsi, E.; Katsouras, A.; Zissimou, G.A.; Gregoriou, V.G.; Avgeropoulos, A.; Koutentis, P.A. $4 \mathrm{H}-1,2,6$-Thiadiazine-containing donor-acceptor conjugated polymers: Synthesis, optoelectronic characterization and their use in organic solar cells. J. Mater. Chem. C 2018, 6, 3658-3667. [CrossRef]

13. Hermerschmidt, F.; Kalogirou, A.S.; Min, J.; Zissimou, G.A.; Tuladhar, S.M.; Ameri, T.; Faber, H.; Itskos, G.; Choulis, S.A.; Anthopoulos, T.D.; et al. 4H-1,2,6-Thiadiazin-4-one-containing small molecule donors and additive effects on their performance in solution-processed organic solar cells. J. Mater. Chem. C 2015, 3, 2358-2365. [CrossRef]

14. Gómez, T.; Macho, S.; Miguel, D.; Neo, A.G.; Rodríguez, T.; Torroba, T. Cyclopentathiadiazines, Cyclohepta- and Cyclopentadithiazoles: New Materials and a Rich Heterocyclic Chemistry of Cyclic Enaminonitriles. Eur. J. Org. Chem. 2005, 2005, 5055-5066. [CrossRef]

15. Asquith, C.R.M.; Godoi, P.H.; Couñago, R.M.; Laitinen, T.; Scott, J.W.; Langendorf, C.G.; Oakhill, J.S.; Drewry, D.H.; Zuercher, W.J.; Koutentis, P.A.; et al. 1,2,6-Thiadiazinones as Novel Narrow Spectrum Calcium/Calmodulin-Dependent Protein Kinase Kinase 2 (CaMKK2) Inhibitors. Molecules 2018, 23, 1221. [CrossRef]

16. Kristinson, H. Addition of sulfenyl chlorides to the cyanogen bond in activated nitriles. Tetrahedron Lett. 1973, 14, 4489-4490. [CrossRef]

17. Kalogirou, A.S.; Koutentis, P.A. The chemistry of non-S-oxidised 4H-1,2,6-thiadiazines. Targets Heterocycl. Syst. 2018, 22, 82-118. [CrossRef]

18. Geevers, J.; Trompen, W.P. Synthesis and reactions of 3,5-dichloro-4H-1,2,6-thiadiazin-4-one. Recl. Trav. Chim. Pays-Bas 1974, 93, 270-272. [CrossRef]

19. Roskoski, R. Properties of FDA-approved small molecule protein kinase inhibitors: A 2021 update. Pharmacol. Res. 2021, 165, 105463. [CrossRef]

20. Clark, M.J.; Miduturu, C.; Schmidt, A.G.; Zhu, X.; Pitts, J.D.; Wang, J.; Potisopon, S.; Zhang, J.; Wojciechowski, A.; Hann, C.J.J.; et al. GNF-2 Inhibits Dengue Virus by Targeting Abl Kinases and the Viral E Protein. Cell Chem. Biol. 2016, 23, 443-452. [CrossRef] [PubMed]

21. Vagnozzi, R.J.; Gatto, G.J.; Kallander, L.S.; Hoffman, N.E.; Mallilankaraman, K.; Ballard, V.L.; Lawhorn, B.G.; Stoy, P.; Philp, J.; Graves, A.P.; et al. Inhibition of the cardiomyocyte-specific kinase TNNI3K limits oxidative stress, injury, and adverse remodeling in the ischemic heart. Sci. Transl. Med. 2013, 5, 207. [CrossRef] [PubMed]

22. Philp, J.; Lawhorn, B.G.; Graves, A.P.; Shewchuk, L.; Rivera, K.R.; Jolivette, L.J.; Holt, D.A.; Gatto, G.J.; Kallander, L.S. 4,6Diaminopyrimidines as Highly Preferred Troponin I-Interacting Kinase (TNNI3K) Inhibitors. J. Med. Chem. 2018, 61, $3076-3088$. [CrossRef] [PubMed]

23. Sivakumaren, S.C.; Shim, H.; Zhang, T.; Ferguson, F.M.; Lundquist, M.R.; Browne, C.M.; Seo, H.S.; Paddock, M.N.; Manz, T.D.; Jiang, B.; et al. Targeting the PI5P4K Lipid Kinase Family in Cancer Using Covalent Inhibitors. Cell Chem. Biol. 2020, $27,525-537$. [CrossRef] [PubMed]

24. Elkins, J.M.; Fedele, V.; Szklarz, M.; Abdul Azeez, K.R.; Salah, E.; Mikolajczyk, J.; Romanov, S.; Sepetov, N.; Huang, X.P.; Roth, B.L.; et al. Comprehensive characterization of the Published Kinase Inhibitor Set. Nat. Biotechnol. 2016, 34, 95-103. [CrossRef] [PubMed]

25. Drewry, D.H.; Wells, C.I.; Andrews, D.M.; Angell, R.; Al-Ali, H.; Axtman, A.D.; Capuzzi, S.J.; Elkins, J.M.; Ettmayer, P.; Frederiksen, M.; et al. Progress towards a public chemogenomic set for protein kinases and a call for contributions. PLoS ONE 2017, 12, e0181585. [CrossRef] [PubMed]

26. Wells, C.I.; Al-Ali, H.; Andrews, D.M.; Asquith, C.R.M.; Axtman, A.D.; Dikic, I.; Ebner, D.; Ettmayer, P.; Fischer, C.; Frederiksen, M.; et al. The Kinase Chemogenomic Set (KCGS): An Open Science Resource for Kinase Vulnerability Identification. Int. J. Mol. Sci. 2021, 22, 566. [CrossRef] [PubMed]

27. Ioannidou, H.A.; Kizas, C.; Koutentis, P.A. Palladium Catalyzed C-C Coupling Reactions of 3,5-Dichloro-4H-1,2,6-thiadiazin-4one. Org. Lett. 2011, 13, 3466-3469. [CrossRef] [PubMed]

28. Ioannidou, H.A.; Koutentis, P.A. Synthesis of asymmetric 3,5-diaryl-4H-1,2,6-thiadiazin-4-ones via Suzuki-Miyaura and Stille coupling reactions. Tetrahedron 2012, 68, 7380-7385. [CrossRef]

29. Kalogirou, A.S.; Koutentis, P.A. Pd-catalyzed C-N Coupling of Primary (Het)arylamines with 5-Substituted 3-Chloro-4H-1,2,6thiadiazin-4-ones. Tetrahedron Lett. 2018, 59, 2653-2656. [CrossRef]

30. Xing, L.; Klug-Mcleod, J.; Rai, B.; Lunney, E.A. Kinase hinge binding scaffolds and their hydrogen bond patterns. Bio. Med. Chem. 2015, 23, 6520-6527. [CrossRef]

31. Dubinina, G.G.; Chupryna, O.O.; Platonov, M.O.; Borisko, P.O.; Ostrovska, G.V.; Tolmachov, A.O.; Shtil, A.A. In silico design of protein kinase inhibitors: Successes and failures. Anticancer Agents Med. Chem. 2007, 7, 171-188. [CrossRef]

32. Mukherjee, P.; Bentzien, J.; Bosanac, T.; Mao, W.; Burke, M.; Muegge, I. Kinase crystal miner: A powerful approach to repurposing 3D hinge binding fragments and its application to finding novel bruton tyrosine kinase inhibitors. J. Chem. Inf. Model. 2017, 57, 2152-2160. [CrossRef]

33. Asquith, C.R.M.; Fleck, N.; Torrice, C.D.; Crona, D.J.; Grundner, C.; Zuercher, W.J. Anti-tubercular activity of novel 4anilinoquinolines and 4-anilinoquinazolines. Bioorg. Med. Chem. Lett. 2019, 29, 2695-2699. [CrossRef]

34. Asquith, C.R.M.; Maffuid, K.A.; Laitinen, T.; Torrice, C.D.; Tizzard, G.J.; Crona, D.J.; Zuercher, W.J. Targeting an EGFR Water Network with 4-Anilinoquin(az)oline Inhibitors for Chordoma. ChemMedChem 2019, 14, 1693-1700. [CrossRef] 
35. Maffuid, K.A.; Koyioni, M.; Torrice, C.D.; Murphy, W.A.; Mewada, H.K.; Koutentis, P.A.; Crona, D.J.; Asquith, C.R.M. Design and evaluation of 1,2,3-dithiazoles and fused 1,2,4-dithiazines as anti-cancer agents. Bioorganic Med. Chem. Lett. 2021, $43,128078$. [CrossRef]

36. Asquith, C.R.M.; Naegeli, K.M.; East, M.P.; Laitinen, T.; Havener, T.M.; Wells, C.I.; Johnson, G.L.; Drewry, D.H.; Zuercher, W.J.; Morris, D.C. Design of a Cyclin G Associated Kinase (GAK)/Epidermal Growth Factor Receptor (EGFR) Inhibitor Set to Interrogate the Relationship of EGFR and GAK in Chordoma. J. Med. Chem. 2019, 62, 4772-4778. [CrossRef]

37. Gillet, J.; Varma, S.; Gottesman, M.M.J. The clinical relevance of cancer cell lines. Natl. Cancer Inst. 2013, 105, 452-458. [CrossRef]

38. Hao, C.; Zhao, F.; Song, H.; Guo, J.; Li, X.; Jiang, X.; Huan, R.; Song, S.; Zhang, Q.; Wang, R.; et al. Structure-based design of 6-chloro-4-aminoquinazoline-2-carboxamide derivatives as potent and selective p21-activated kinase 4 (PAK4) inhibitors. J. Med. Chem. 2018, 61, 265-285. [CrossRef]

39. Tan, X.; Tester, R.W.; Luedtke, G.R.; Chakravarty, S.; Mavunkel, B.J.; Perumattam, J.J.; Lu, Q.; Nashashibi, I.; Jung, J.; Hu, J.; et al. Design and synthesis of piperazine-indole p38 alpha MAP kinase inhibitors with improved pharmacokinetic profiles. Bioorg. Med. Chem. Lett. 2010, 20, 828-831. [CrossRef]

40. Safina, B.S.; Baker, S.; Baumgardner, M.; Blaney, P.M.; Chan, B.K.; Chen, Y.-H.; Cartwright, M.W.; Castanedo, G.; Chabot, C.; Cheguillaume, A.J.; et al. Discovery of novel PI3-kinase $\delta$ specific inhibitors for the treatment of rheumatoid arthritis: Taming CYP3A4 time-dependent inhibition. J. Med. Chem. 2012, 55, 5887-5900. [CrossRef]

41. Talele, T.T. Natural-Products-Inspired Use of the gem-Dimethyl Group in Medicinal Chemistry. J. Med. Chem. 2018, 61, 2166-2210. [CrossRef]

42. Kalogirou, A.S.; Asquith, C.R.M.; Koutentis, P.A. Synthesis of (R) and (S)-3-Chloro-5-(2,4-dimethylpiperazin-1-yl)-4H-1,2,6thiadiazin-4-ones. Molbank 2020, 2020, M1139. [CrossRef]

43. Crawford, T.D.; Ndubaku, C.O.; Chen, H.; Boggs, J.W.; Bravo, B.J.; DeLaTorre, K.; Giannetti, A.M.; Gould, S.E.; Harris, S.F.; Magnuson, S.R.; et al. Discovery of selective 4-amino-pyridopyrimidine inhibitors of MAP4K4 using fragment-based lead identification and optimization. J. Med. Chem. 2014, 57, 3484-3493. [CrossRef] [PubMed]

44. Strang, B.L.; Asquith, C.R.M.; Moshrif, H.F.; Ho, C.M.K.; Zuercher, W.J.; Al-Ali, H. Identification of lead anti-human cytomegalovirus compounds targeting MAP4K4 via machine learning analysis of kinase inhibitor screening data. PLoS ONE 2018, 13, e0201321. [CrossRef] [PubMed]

45. Asquith, C.R.M.; Laitinen, T.; Bennett, J.M.; Godoi, P.H.; East, M.P.; Tizzard, G.H.; Graves, L.M.; Johnson, G.L.; Dornsife, R.E.; Wells, C.I.; et al. Identification and optimization of 4-anilinoquinolines as inhibitors of cyclin $\mathrm{G}$ associated kinase. ChemMedChem 2018, 13, 48-66. [CrossRef] [PubMed]

46. Duncan, J.S.; Whittle, M.C.; Nakamura, K.; Abell, A.N.; Midland, A.A.; Zawistowski, J.S.; Johnson, N.L.; Granger, D.A.; Jordan, N.V.; Darr, D.B.; et al. Dynamic reprogramming of the kinome in response to targeted MEK inhibition in triple-negative breast cancer. Cell 2012, 149, 307-321. [CrossRef]

47. Tung, R.M.; Blenis, J. A novel human SPS1/STE20 homologue, KHS, activates Jun N-terminal kinase. Oncogene 1997, 14, 653-659. [CrossRef]

48. Diener, K.; Wang, X.S.; Chen, C.; Meyer, C.F.; Keesler, G.; Zukowski, M.; Tan, T.H.; Yao, Z. Activation of the c-Jun N-terminal kinase pathway by a novel protein kinase related to human germinal center kinase. Proc. Natl. Acad. Sci. USA 1997, 94, 9687-9692. [CrossRef]

49. Duquesnes, N.; Lezoualc'h, F.; Crozatier, B. PKC-delta and PKC-epsilon: Foes of the same family or strangers? J. Mol. Cell Cardiol. 2011, 51, 665-673. [CrossRef]

50. Watanabe, G.; Saito, Y.; Madaule, P.; Ishizaki, T.; Fujisawa, K.; Morii, N.; Mukai, H.; Ono, Y.; Kakizuka, A.; Narumiya, S. Protein kinase N (PKN) and PKN-related protein rhophilin as targets of small GTPase Rho. Science 1996, 271, 645-648. [CrossRef]

51. Small-Molecule Drug Discovery Suite 2020-4; Schrödinger, LLC: New York, NY, USA, 2020.

52. Staal, S.P. Molecular cloning of the akt oncogene and its human homologues AKT1 and AKT2: Amplification of AKT1 in a primary human gastric adenocarcinoma. Proc. Natl. Acad. Sci. USA 1987, 84, 5034-5037. [CrossRef]

53. Goyal, P.; Behring, A.; Kumar, A.; Siess, W. Identifying and characterizing a novel protein kinase STK35L1 and deciphering its orthologs and close-homologs in vertebrates. PLoS ONE. 2009, 4, e6981. [CrossRef]

54. Cárcamo, J.; Weis, F.M.; Ventura, F.; Wieser, R.; Wrana, J.L.; Attisano, L.; Massagué, J. Type I receptors specify growth-inhibitory and transcriptional responses to transforming growth factor beta and activin. Mol. Cell Biol. 1994, 14, 3810-3821. [CrossRef] [PubMed]

55. Kalogirou, A.S.; Koutentis, P.A. A Qualitative Comparison of the Reactivities of 3,4,4,5-Tetrachloro-4H-1,2,6-thiadiazine and 4,5-Dichloro-1,2,3-dithiazolium Chloride. Molecules 2015, 20, 14576-14594. [CrossRef] [PubMed]

56. Attwood, M.M.; Fabbro, D.; Sokolov, A.V.; Knapp, S.; Schiöth, H.B. Trends in kinase drug discovery: Targets, indications and inhibitor design. Nat. Rev. Drug Discov. 2021, in press. [CrossRef]

57. Cohen, P.; Alessi, D.R. Kinase drug discovery-what's next in the field? ACS Chem. Biol. 2013, 8, 96-104. [CrossRef] [PubMed]

58. Fedorov, O.; Müller, S.; Knapp, S. The (un)targeted cancer kinome. Nat. Chem. Biol. 2010, 6, 166-169. [CrossRef]

59. Rudolf, A.F.; Skovgaard, T.; Knapp, S.; Jensen, L.J.; Berthelsen, J. A comparison of protein kinases inhibitor screening methods using both enzymatic activity and binding affinity determination. PLoS ONE 2014, 9, e98800. [CrossRef] [PubMed]

60. Davis, M.I.; Hunt, J.P.; Herrgard, S.; Ciceri, P.; Wodicka, L.M.; Pallares, G.; Hocker, M.; Treiber, D.K.; Zarrinkar, P.P. Comprehensive analysis of kinase inhibitor selectivity. Nat. Biotechnol. 2011, 29, 1046-1051. [CrossRef] [PubMed] 
61. Fabian, M.A.; Biggs, W.H.; Treiber, D.K.; Atteridge, C.E.; Azimioara, M.D.; Benedetti, M.G.; Carter, T.A.; Ciceri, P.; Edeen, P.T.; Floyd, M.; et al. A small molecule-kinase interaction map for clinical kinase inhibitors. Nat. Biotechnol. 2005, 23, 329-336. [CrossRef] [PubMed]

62. Klaeger, S.; Heinzlmeir, S.; Wilhelm, M.; Polzer, H.; Vick, B.; Koenig, P.-A.; Reinecke, M.; Ruprecht, B.; Petzoldt, S.; Meng, C.; et al. The target landscape of clinical kinase drugs. Science 2017, 358, eaan4368. [CrossRef]

63. Ma, X.; Deacon, S.; Horiuchi, K. The challenge of selecting protein kinase assays for lead discovery optimization. Expert Opin. Drug Discov. 2008, 3, 607-621. [CrossRef]

64. Elwaie, T.A.; Abbas, S.E.; Aly, E.I.; George, R.F.; Ali, H.; Kraiouchkine, N.; Abdelwahed, K.S.; Fandy, T.E.; El Sayed, K.A.; Elmageed, Z.Y.A.; et al. HER2 kinase-targeted breast cancer therapy: Design, synthesis, and in vitro and in vivo evaluation of novel lapatinib congeners as selective and potent HER2 inhibitors with favorable metabolic stability. J. Med. Chem. 2020, 63, 15906-15945. [CrossRef]

65. Santoni, M.; Amantini, C.; Morelli, M.B.; Liberati, S.; Farfariello, V.; Nabissi, M.; Bonfili, L.; Eleuteri, A.M.; Mozzicafreddo, M.; Burattini, L.; et al. Pazopanib and sunitinib trigger autophagic and non-autophagic death of bladder tumour cells. Br. J. Cancer 2013, 109, 1040-1050. [CrossRef]

66. Mehdi, O.; Françoise, S.; Sofia, C.L.; Urs, G.; Kevin, Z.; Bernard, S.; Igor, S.; Anabela, C.; Dominique, L.; Eric, M.; et al. HDAC gene expression in pancreatic tumor cell lines following treatment with the HDAC inhibitors panobinostat (LBH589) and trichostatine (TSA). Pancreatology 2012, 12, 146-155. [CrossRef]

67. Mabuchi, M.; Ueda, M.; Yoshida, Y.; Horiike, K.; Yamaoka, K.; Nakao, S.; Shimizu, T.; Ueda, Y.; Tsujikawa, K.; Tanaka, A. Systematic trial for evaluating docetaxel in a human prostate cancer cell DU145 xenograft model. Anticancer Res. 2017, 37, 1665-1676. [CrossRef]

68. Cha, M.Y.; Lee, K.; Kim, J.W.; Lee, C.G.; Song, J.Y.; Kim, Y.H.; Lee, G.S.; Park, S.B.; Kim, M.S. Discovery of a novel Her-1/Her-2 dual tyrosine kinase inhibitor for the treatment of Her-1 selective inhibitor-resistant non-small cell lung cancer. J. Med. Chem. 2009, 52, 6880-6888. [CrossRef]

69. Collins, K.A.L.; Stuhlmiller, T.; Zawistowski, J.J.S.; East, M.P.; Pham, T.T.; Hall, C.R.; Goulet, D.R.; Bevill, S.M.; Angus, S.P.; Velarde, S.H.; et al. Proteomic analysis defines kinase taxonomies specific for subtypes of breast cancer. Oncotarget 2018, 9, 15480-15497. [CrossRef]

70. Marcotte, D.; Rushe, M.M.; Arduini, R.; Lukacs, C.; Atkins, K.; Sun, X.; Little, K.; Cullivan, M.; Paramasivam, M.; Patterson, T.A.; et al. Germinal-center kinase-like kinase co-crystal structure reveals a swapped activation loop and C-terminal extension. Protein Sci. 2017, 26, 152-162. [CrossRef] [PubMed]

71. Chamberlain, P.; Delker, S.; Pagarigan, B.; Mahmoudi, A.; Jackson, P.; Abbasian, M.; Muir, J.; Raheja, N.; Cathers, B. Crystal structures of PRK1 in complex with the clinical compounds lestaurtinib and tofacitinib reveal ligand induced conformational changes. PLoS ONE 2014, 9, e103638. [CrossRef] [PubMed]

72. McHardy, T.; Caldwell, J.J.; Cheung, K.M.; Hunter, L.J.; Taylor, K.; Rowlands, M.; Ruddle, R.; Henley, A.; de Haven, B.A.; Valenti, M.; et al. Discovery of 4-amino-1-(7H-pyrrolo[2,3-d]pyrimidin-4-yl)piperidine-4-carboxamides as selective, orally active inhibitors of protein kinase B (Akt). J. Med. Chem. 2010, 53, 2239-2249. [CrossRef] [PubMed]

73. Tebben, A.J.; Ruzanov, M.; Gao, M.; Xie, D.; Kiefer, S.E.; Yan, C.; Newitt, J.A.; Zhang, L.; Kim, K.; Lu, H.; et al. Crystal structures of apo and inhibitor-bound TGF $\beta$ R2 kinase domain: Insights into TGF $\beta$ R isoform selectivity. Acta Crystallogr. D Struct. Biol. 2016, 72, 658-674. [CrossRef]

74. Jumper, J.; Evans, R.; Pritzel, A.; Green, T.; Figurnov, M.; Ronneberger, O.; Tunyasuvunakool, K.; Bates, R.; Žídek, A.; Potapenko, A.; et al. Highly accurate protein structure prediction with AlphaFold. Nature 2021, 596, 583-589. [CrossRef]

75. Harwood, L.M. “Dry-Column” Flash Chromatography. Aldrichimica Acta 1985, 18, 25. 